\title{
ANCANGAN MODEL KERANGKA TEORI KESANTUNAN YANG EFEKTIF MENGKAJI BUDAYA BAHASA-BAHASA WARISAN DI ASIA: REVIEW TERHADAP KEUNIVERSALAN KERANGKA TEORI KESANTUNAN BROWN \& LEVINSON
}

\author{
Abdul Hakim Yassi* \\ Universitas Hasanuddin \\ hakimyassi@yahoo.com
}

\begin{abstract}
Abstrak
Artikel ini menguji keefektifan serta keselarasan model kerangka teori kesantunan Yassi (1996, 2011), yang diadaptasi dari Brown \& Levinson (1978, 1987) dan Scollon \& Scollon (1983, 1995), terhadap bahasa warisan di Indonesia dan di Asia pada umumnya. Data dalam bentuk transkripsi rekaman tuturan beberapa bahasa etnis di Sulawesi Selatan dianalisis dengan menggunakan kerangka teori ini. Analisis data membuktikan kesesuaian ancangan ini dan sekaligus menunjukkan kegagalan kerangka teori Brown \& Levinson dalam membedakan interaksi yang berpola kekerabatan dari interaksi yang berkategori non-kerabat. Pola strategi kesantunan pada interaksi akrab berkerabat, misalnya antarsaudara, berbeda dari yang berpola akrab non-kerabat, misalnya percakapan antarteman. Percakapan antarsaudara cenderung asimetri, sementara percakapan antarteman cenderung simetri. Perbedaan ini tentu saja berdampak pada pilihan strategi kesantunan oleh peserta tutur. Antarteman menggunakan kesantunan positif, sementara pada interaksi antarsaudara, kakak mnggunakan kesantunan positif, adik menggunakan kesantunan negatif. Demikian pula yang terjadi pada interaksi asimetri berbasis kekerabatan, misalnya, antara suami-istri-anak dan yang berbasis nonkerabat, misalnya atasan-bawahan.
\end{abstract}

Kata kunci: kesantunan negatif, kesantunan positif, keuniversalan

\begin{abstract}
The article revisits the effectiveness and compatibility of Yassi's politeness theoretical framework (1996, 2011), adapting Brown \& Levinson's (1978, 1987) and Scollon \& Scollon's (1995) frameworks, in studying politeness system of heritage languages in Indonesia and Asia in general. The data consisting of transcription of recorded utterances of some heritage languages in South Sulawesi were analyzed employing Yassi's framework. The study reveals that Brown \& Levinson's framework fails to distinguish a kinship-based interaction from those of non-kinship one. Intimacy on kinship relations, like interaction between siblings denoted different behaviors from those of among friends. The former tended to be asymmetrical where the elder employed positive politeness and the younger used negative politeness. The latter tended to be symmetrical where all participants tended to employ positive politeness. Similar behavior also denoted by a kinship-based asymmetrical interaction, for instance, interaction among husbandwife-children, which is completely different from those of non-kinship one such as interaction between a boss and his/her subordinates.
\end{abstract}

Keywords: negative politeness, positive politeness, universality 


\section{PENDAHULUAN}

Konsep kesantunan dalam masyarakat merupakan suatu hal yang mutlak dimiliki oleh peserta tutur. Salah satu variabel yang sangat menentukan suksesnya suatu komunikasi adalah sejauh mana konsep ini dapat diaplikasikan secara proporsional oleh peserta tutur yang terlibat. Kesantunan memiliki beberapa fungsi sosial dalam suatu interaksi antarindividu, antara lain, menciptakan interaksi yang harmonis, menunjukkan rasa hormat, dan lain sebagainya. Kesantunan juga merupakan suatu strategi berkomunikasi yang efektif untuk menghindari terjadinya konflik antarindividu yang berpotensi menjadi konflik pada skala yang lebih besar seperti konflik antarkelompok, antarkampung, atau antaretnik (lihat Yassi, 2016c, 2016d).

Konsep kesantunan atau politeness berasal dari bahasa Latin politus yang berarti diperhalus (smoothed) dan dirias (polished). Dengan demikian, kesantunan merujuk pada perilaku sosial atau etika yang harus digunakan oleh peserta tutur dalam berkomunikasi sehingga terjadi komunikasi yang positif antara peserta tutur, misalnya lawan tutur merasa nyaman dan terhindar dari perasaan malu atau tersinggung. Menurut Brown \& Levinson (1978) (selanjutnya B\&L), konsep kesantunan adalah ungkapan keinginan penutur untuk memperkecil ancaman muka lawan tutur yang dipicu oleh tindak tutur tertentu yang mengancam muka (Face Threatening Acts atau FTAs) lawan tutur. Artikel ini bertujuan untuk menawarkan suatu ancangan model teori kesantunan yang penulis yakini efektif untuk mengkaji fenomena kesantunan bukan saja budaya bahasa-bahasa etnik Sulawesi Selatan, melainkan juga efektif terhadap budaya bahasa-bahasa etnik lainnya di Indonesia dan bahkan di Asia. Ancangan ini bertumpu sepenuhnya pada tiga variabel sosial, yakni Power (selanjutnya disingkat P) yang merujuk pada status sosial atau otoritas peserta tutur, Distance (selanjutnya disingkat D) yang merujuk pada tingkat keakraban peserta tutur, dan Kinship (selanjutnya disingkat K) yang menunjukkan tingkat kekerabatan peserta tutur.

\section{KERANGKA TEORI}

Fenomena kesantunan akan beragam dari satu budaya ke budaya lainnya. Dengan kata lain, setiap kebudayaan memiliki kekhasan terhadap aplikasi konsep kesantunan. Lakoff (1990) mengatakan bahwa kebudayaan dalam mematuhi kesantunan selalu memperhatikan tiga variabel sosial, yakni jarak (distance), kepatuhan (deference), dan persahabatan (camaraderie). Jarak ditandai sebagai strategi impersonalitas, kepatuhan sebagai strategi keraguan, dan persahabatan sebagai strategi informalitas. Menurut Lakoff, kebudayaan Asia secara garis besar cenderung mengambil strategi kepatuhan, kebudayaan Eropa cenderung menggunakan strategi jarak, sedangkan kebudayaan Amerika cenderung menerapkan strategi persahabatan. Lakoff (1973) juga memperkenalkan tiga strategi kesantunan: (1) jangan mengganggu, (2) berikan pilihan, dan (3) buatlah pilihan yang menyenangkan lawan tutur atau bersikap ramah terhadap lawan tutur.

Berbeda dengan Lakoff, B\&L (1978) memperkenalkan teori kesantunan yang sama sekali berbeda dan diklaim memiliki sifat universal. Teori ini berfokus pada dua aspek, yakni "rasionalitas" dan "wajah" atau "muka" (face) yang terdiri atas dua "keinginan", yakni Muka Positif (positive face) dan Muka Negatif (negative face). Muka Positif merupakan citra diri seseorang yang berkaitan dengan keinginannya untuk senantiasa mendapat apresiasi atau respek dari komunitas di mana mereka berada. Muka Negatif adalah citra diri seseorang yang berkaitan dengan keinginannya untuk tidak diintervensi atau diinvasi otoritasnya. Muka Positif mengacu 
pada Kesantunan Positif, yakni strategi bertutur dengan cara menekankan aspek kedekatan, keakraban, dan hubungan baik antara peserta tutur, sedangkan Muka Negatif mengacu pada Kesantunan Negatif, yakni strategi bertutur dengan menunjukkan adanya jarak sosial di antara peserta tutur (Scollon \& Scollon, 1995, selanjutnya disebut S\&S).

Terlepas dari popularitas kerangka teori B\&L ini, dalam perjalanannya sejak diluncurkan kurang lebih empat dasawarsa yang lalu, kerangka teori B\&L telah mendapat banyak tantangan atas aspek keuniversalannya, terutama yang berasal dari kajian-kajian yang berbasis budaya Asia, antara lain Kitagawa (1980), Ide (1989), Gu (1990), Nwoye (1992), Agus (2013), dan Yassi (1996, 2011, 2012, 2016b, 2016c, 2016d). Hasil penelitian Yassi memperlihatkan bahwa hal ini dimotivasi oleh perbedaan fundamental pada aspek budaya yang membangun teori B\&L, yakni budaya Eropa dan Amerika yang tentu saja berbeda dengan budaya Asia seperti yang dikatakan oleh Lakoff (1990) di atas. Budaya Eropa menekankan aspek jarak (distance), budaya Amerika menekankan aspek keabraban (intimacy), sedangkan budaya Asia menekankan aspek hormat (deference).

Kerangka teori kesantunan Yassi merupakan hasil adaptasi dan pengembangan dari teori kesantunan B\&L $(1978,1987)$ dan S\&S $(1983,1995)$. Yassi (1996) mengembangkan pola kesantunan menjadi enam sistem: (1) Hormat tidak berkerabat dengan konfigurasi (-P,+D,-K), contoh: interaksi antara orang yang tidak saling mengenal; (2) Hormat berkerabat dengan konfigurasi $(-\mathrm{P},+\mathrm{D},+\mathrm{K})$, contoh: interaksi antara keluarga jauh; (3) Akrab tidak berkerabat dengan konfigurasi (-P,-D,-K), contoh: interaksi antara teman; (4) Akrab berkerabat dengan konfigurasi (-P,-D,+K), contoh: interaksi antara keluarga dekat; (5) Hirarki tidak berkerabat dengan konfigurasi $(+\mathrm{P},+\mathrm{D},-\mathrm{K})$, contoh: interaksi antara atasan-bawahan, dan (6) Hirarkhi berkerabat dengan konfigurasi $(+\mathrm{P},-\mathrm{D},+\mathrm{K})$, contoh: interaksi antara orang tua dan anak, paman dan kemenakan, kakek/nenek dan cucu/cicit, di mana $\mathrm{P}$ berarti kekuasaan (power) atau status sosial, D berarti jarak (distance), dan K berarti kerabat (kinship). Tanda (+) berarti aspek atau karakter yang tersebut ada, sedangkan tanda (-) menunjukkan bahwa karakter yang tersebut tidak ada. Diyakini bahwa ketiga variabel sosial inilah (P,D,K) yang berkontribusi positif terhadap strategi kesantunan yang dipilih oleh penutur pada saat berkomunikasi dengan lawan tutur mereka. Diagram berikut ini memperjelas kategori dan arah kerangka teori Yassi tersebut.

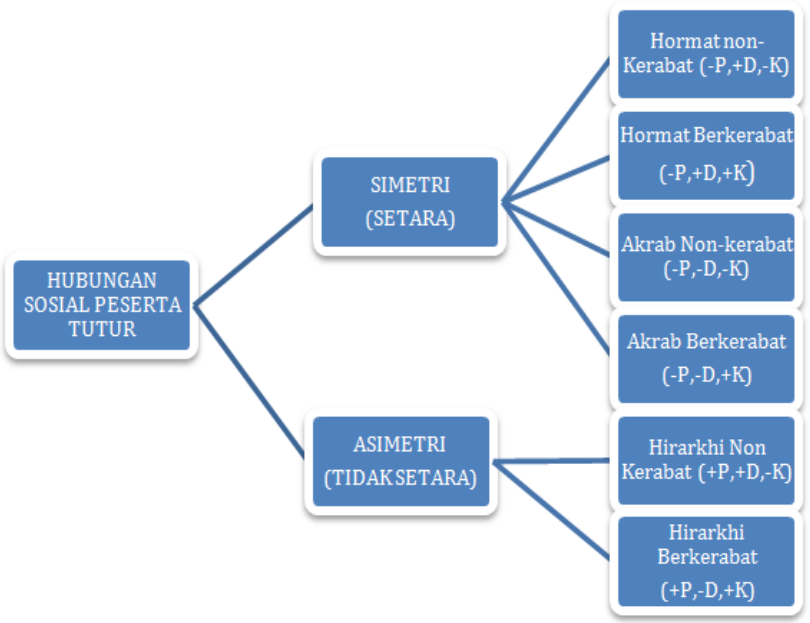

Diagram 1. Enam Pola Interaksi Sosial Kesantunan Yassi $(1996,2011)$ 


\section{DATA DAN ANALISIS DATA}

Data penelitian dikutip dari beberapa penelitian penulis tentang sistem kesantunan budaya bahasa-bahasa etnik di Sulawesi Selatan (Yassi, 1996, 2011b, 2012, 2016b, 2016c, dan 2016d). Data kemudian dianalisis dengan menggunakan model kerangka teori kesantunan yang dibangun oleh Yassi (1996, 2012).

Data dalam bentuk transkripsi rekaman tuturan dari empat etnik utama di Sulawesi Selatan, yakni Makassar (dikutip dari Yassi, 1996, 2011b, 2012), Enrekang, Toraja, dan Tae' Palopo (dikutip dari Yassi, 2016b, 2016c, 2016d), dianalisis dengan menggunakan model kerangka teori yang dikembangkan oleh Yassi $(1996,2012)$. Analisis data akan diarahkan selain untuk menemukan pola strategi kesantunan dari keempat etnik tersebut, analisis ini juga untuk menguji tingkat keuniversalan serta kompatibilitas kerangka teori kesantunan yang dibangun oleh penulis (Yassi, 1986, 2011) terhadap budaya bahasa-bahasa etnis di Sulawesi Selatan.

\section{Bahasa Makassar}

Di bawah ini analisis pola serta strategi kesantunan budaya bahasa Makassar.

1. Hormat tidak berkerabat $(-\mathrm{P},+\mathrm{D},-\mathrm{K})$

Dua data di bawah ini menunjukkan pola strategi kesantunan hormat tidak berkerabat. Dialog (1a) antara dua orang yang tidak saling mengenal ( $A=$ tokoh masyarakat, $B=u l a m a)$, sedangkan dialog (1b) antara dua orang yang baru bertemu ( $\mathrm{A}=$ pengawal raja, $\mathrm{B}=$ orang suci).

(1)a. A. Ikau mintu paleng nakellai tuanta angajarakki? (Jadi kamu yang disuruh oleh pimpinan kami untuk mengajar kami?)

B. Kammaminjo kanangna rinakke. (Begitulah yang diperintahkan kepada saya.)

(1)b. A. Ikau paleng ampassallangi tumalompoku? (Jadi kamu yang mengislamkan raja kami?)

B. Erokna Allah Taala, pangellainna Rasulullahi. (Kemauan Alah S.W.T. dan seizin Rasulullah.)

Seperti terlihat pada kedua interaksi di atas, strategi kesantunan yang digunakan oleh kedua penutur berbeda satu dengan lainnya. Penutur A cenderung menggunakan strategi kesantunan positif, yakni penggunaan ragam tutur yang lebih kasual, yaitu penggunaan bentuk sapaan ikau 'kamu', dan bukan ikatte, yang lebih sopan. Sebaliknya, penutur B cenderung menggunakan kesantunan negatif, yakni menggunakan ragam tutur yang lebih hormat, yang ditunjukkan oleh ragam tutur tak langsung, indirectness, yang digunakan oleh penutur B dalam menanggapi pertanyaan penutur A. Penutur B menjawab secara tidak langsung agar tuturannya terlihat lebih sopan, dan terhindar dari kesan angkuh atau sombong apabila dia menjawab langsung dengan menggunakan bentuk sapaan seperti iye atau iyo 'ya'.

2. Hormat berkerabat $(-\mathrm{P},+\mathrm{D},+\mathrm{K})$

Berikut adalah data percakapan antara dua orang yang berkerabat jauh namun mereka seusia.

(2) A. Eroko mange riballa'na i Sitti? (Kamu mau pergi ke rumah Sitti?)

B. Iyo, anggapai memang. (Ya, ada apa?)

A. Erangngangi anne gollaiya. (Bawakan gula ini.)

B. Kupake paeng motoro'nu rong. (Kalau begitu saya pakai motormu dulu.) 
Seperti terlihat pada dialog di atas, kedua penutur menggunakan strategi kesantunan yang sama, yaitu strategi kesantunan positif, yakni menggunakan ragam tutur yang lebih kasual. Penutur A menggunakan bentuk sapaan yang lebih kasual, yakni sufiks -ko 'kamu, anda', dan bukan $-k i$ yang lebih hormat. Hal yang sama, pada saat merespon, penutur B menggunakan bentuk sapaan iyo 'ya', dan bukan iye yang lebih sopan. Selain itu, penutur A menggunakan kalimat imperatif yang lebih langsung pada saat menyuruh penutur B, dan kemudian dijawab oleh penutur B juga dengan kalimat imperatif dan bentuk sapaan kasual $-n u$ 'kamu, anda', dan bukan - ta yang lebih hormat. Dengan demikian dapat disimpulkan bahwa kedua peserta tutur, meskipun berkerabat jauh, mempunyai hubungan yang sangat akrab sehingga tuturan yang dipilih adalah bentuk sapaan yang lebih kasual.

3. Akrab tidak berkerabat (-P,-D,-K)

Data (3a) dan (3b) adalah percakapan antara dua orang yang bersahabat.

(3)a. Dialog antara A dan B; A sedikit lebih tua dibandingkan dengan B.

A. Anjo kucini Yusupu maramaraeng dudui paccinikku. Kamma tau ammake Ajaajarang. (Saya lihat Yusuf itu agak aneh. Sepertinya dia berilmu.)

B. Kamamemangi antu, katte. (Sepertinya demikian.)

(3)b. Dialog antara dua orang sahabat. A sedikit lebih tua dibanding B.

A. Astaga, ikauka antu Kebo, Battu kemaeko? (Astaga, kamukah itu Kebo, kamu dari mana?)

B. Astaga, Dg Mene, Kaikatte padeng. Antama tongko rinni arisan. Takuciniki sumpaeng maki eh. (Astaga, Dg Mene, ternyata itu kamu. Ikut pulalah arisan di sini. Saya tidak melihat kamu tadi.)

A. Antekamma antu mae kabaraka? Bajik-bajik jaki?(Bagaimana kabarnya? Baikbaik bukan?)

B. Iyek, bajik-bajikji. Sangkamma-kammanami anjo. Maeki ajjappa-japa riballa. Barang katenamoseng kiciniki ballaku. (Ya, baik-baik saja. Seperti itulah selalu. Jalan-jalanlah ke rumah. Barangkali sudah tidak lihat rumah saya.)

A. Iyo... Ba, iyo. Lalampa tonja ri balla'nu. Apalagi punna naiki arisanga, riballa ngaseng maki. (Ya, tentu saja masih lihat. Saya juga akan ke rumahmu. Apalagi kalau arisannya naik. Di rumah saya saja sekalian.)

Ragam tutur yang digunakan peserta tutur pada kedua dialog di atas adalah gabungan antara bentuk sapaan yang bersifat kasual dan hormat. Hal ini ditandai dengan penggunaan bentuk sapaan seperti ikau 'kamu, anda', sufiks -ko 'kamu', dan iyo 'ya' yang digunakan oleh kedua penutur, meskipun sekali-kali mereka juga menggunakan bentuk sapaan yang lebih sopan, seperti iyek 'ya', ikatte 'kamu', dan sufiks -ki 'kamu'.

Selanjutnya, terlihat pula dari data di atas bahwa penggunaan ragam yang lebih kasual didominasi secara konsisten oleh penutur A, sementara penutur B umumnya menggunakan ragam yang lebih hormat atau sopan secara konsisten. Hal ini disebabkan oleh perbedaan usia kedua peserta tutur. Meskipun kedua peserta tutur merupakan sahabat, tetapi mereka sedikit berbeda usia. Penutur A sedikit lebih tua dibandingkan dengan penutur B. Oleh sebab itu, penutur A cenderung menggunakan strategi kesantunan positif atau penggunaan ragam yang lebih kasual, sementara penutur B yang lebih muda usianya secara konsisten tetap menggunakan strategi kesantunan negatif, yakni penggunaan ragam tutur yang lebih hormat. 
4. Akrab berkerabat $(-\mathrm{P},-\mathrm{D},+\mathrm{K})$

Dialog (4) di bawah ini merepresentasikan interaksi antara penutur dalam keluarga dekat $(\mathrm{A}=$ Kakak, B = Adik).

(4) A. O.. andik niak erok kupawwangangko. (Dik, ada yang ingin saya beritahukan.)

B. Apa njo ka'? (Apakah itu, kak?)

A. Erokka pala tolong, bicarako rong sigang bapak. (Saya mau minta tolong. Sampaikan kepada bapak.)

B. Apa erok ni kana ka'? Ngapaki kah? (Mau bilang apakah, kak? Ada apakah, kak?)

A. Kammanne eroka pala doe' mingka malla'-malla' tonga. (Begini, saya mau minta uang, tetapi saya takut.)

B. Malla' apaki? Eroki kiapa anjo doeka? (Apa yang ditakutkan? Untuk apa uang itu?)

A. Eroka pakei a'bayara kulia ndi', ka pa 'bayara kulia ku nungga mi. (Saya mau bayar uang kuliahku yang menunggak.)

B. Iye sallangpi kuagangki a'bicara ribapak, mingka ngapa nakkulle pa 'bayara kuliata kulle nungga? (Ya, nanti saya temani bila berbicara dengan bapak. Tetapi mengapa bisa menunggak?)

A. Kammanne caritanna anjo riolo attunna pa'bayarrang tena doe' na bapak jari kupalaki rikampusuka dispensasi ndi' kammanjo caritanna. (Ceritanya begini, sewaktu pembayaran, bapak tidak punya uang, sehingga saya minta dispensasi di kampus.)

B. Oh... kammanjo, jari anjo teai katte pata salah kutaeng anjo bapak nakaluppai nasareki doe'. Jari kammamo anne sinampe bangngi punna motere'mi bapak langsung maki a'bicara di! (Oh, begitu. Jadi itu bukan kesalahan kamu.

Kemungkinan bapak lupa memberikan kamu uang. Jadi kalau bapak sudah pulang sebentar, kita langsung saja memberitahukannya, ya!)

A. Iyo pade ndi' tarema kasih ero' jako tolonga ndi'. (Ya, sebaiknya begitu, terima kasih karena kau mau menolong saya, dik.)

Meskipun berada dalam konfigurasi kesantunan akrab (solidarity politeness system), pola strategi kesantunan yang ditunjukkan oleh kedua peserta tutur masih terlihat asimetri. Penutur A pada umumnya menggunakan pola sapaan yang lebih kasual seperti -ko 'kamu', iyo 'ya', tetapi sebaliknya penutur B memilih bentuk sapaan yang lebih formal seperti katte, $-k i$ 'kamu' dan iye 'ya'.

Faktor apakah yang berkontribusi terhadap fenomena ini? Bila kita amati dialog (3a), (3b), dan (4) secara saksama, terlihat jelas bahwa 'aspek senioritas' khususnya perbedaan usia memiliki peran yang krusial terhadap pola strategi kesantunan yang dipilih oleh peserta tutur dalam suatu interaksi. Penutur yang lebih senior (penutur A) cenderung memilih pola sapaan yang lebih kasual, sedangkan penutur B tetap memilih pola sapaan yang lebih sopan karena dia lebih yunior, yakni adik dari penutur B.

Dengan demikian, fenomena ini kembali menunjukkan bahwa aspek keuniversalan teori kesantunan B\&L terbantahkan. Teori ini mengklaim bahwa apabila bentuk interaksi berada dalam konfigurasi solidarity politeness system, pilihan bentuk bahasa peserta tutur cenderung lebih kasual. Ketiga data tersebut di atas secara empiris membuktikan tidak demikian adanya. 
5. Hirarkhi tidak berkerabat $(+\mathrm{P},+\mathrm{D},-\mathrm{K})$

Data berikut ini menggambarkan interaksi antara senior-yunior, atasan-bawahan, dan yang semacamnya.

(5)a. Dialog antara dua orang (A lebih tua dari pada B)

A. Mannanjo tana roso bajikji batena akbua?

(Apakah tetap berbuah dengan baik meskipun tanahnya tidak subur?)

B. Iyek puang, kammaminjo batena napau mantari partanianga.

(Ya pak, begitulah yang dikatakan penyuluh pertanian tersebut.)

(5)b. Dialog antara tuan dan pembantunya $(\mathrm{A}=$ Tuan, $\mathrm{B}=\mathrm{Pembantu})$

A. Niyak sumpaeng tau nucinik ammenteng ri+timunganga? (Adakah seseorang yang kamu lihat berdiri di pintu?)

B. Niyak, karaeng. (Ada, tuan.)

B. Ikatte mamiseng kuparek mangge. (Cuma tuanlah yang saya anggap orang tua saya.)

A. Bajikmi, ikau sikali nakke pissimpulo rannuku. (Baiklah, kegembiraan saya melebihi kamu.)

(5)c. Dialog antara seorang atasan dan bawahannya $(\mathrm{A}=$ Atasan, $\mathrm{B}=$ Bawahan)

A. Erokka ampalettekko mange ri Jarakatta. (Saya ingin memindahkan kamu ke Jakarta.)

B. Kupinawangi kanangta. (Saya mematuhi perintah Bapak.)

Ketiga dialog di atas menunjukkan pola strategi kesantunan yang lebih konsisten yang dipilih oleh peserta tutur. Superior (senior) cenderung memilih pola sapaan yang lebih kasual, sedangkan inferior (yunior) cenderung memilih pola sapaan yang lebih sopan. Penutur B merespon pertanyaan penutur A dengan mengatakan iyek puang 'ya, pak' pada (5a), karaeng, ikatte pada (5b), dan -ta 'Bapak' pada (5c). Hal ini disebabkan oleh status B sebagai inferior (yunior). Sebaliknya, penutur A menggunakan pola sapaan yang lebih kasual seperti $n u$-, ikau 'kamu' pada (5b) dan -ko pada (5c). Hal ini disebabkan oleh status A yang lebih senior.

6. Hirarkhi berkerabat $(+\mathrm{P},-\mathrm{D},+\mathrm{K})$

Data berikut ini adalah interaksi antara orang tua dan anak, paman dan kemenakan, kakek/nenek dan cucu/cicit.

(6)a. Dialog antara suami dan istri $(\mathrm{A}=$ Suami, $\mathrm{B}=\mathrm{Istri})$
A. Taenaka nulekbak langereki paupaunna sitau baine tinggiminasa dudu? (Tidak pernahkah kamu mendengar cerita tentang seorang wanita yang memiliki keinginan yang muluk-muluk?)
B. Taenapa, kipau saibedengmae antu paupaua. (Belum pernah, tolong ceritakan.)

(6)b. Dialog antara suami dan istri (A= Istri, B=Suami)
A. Erok duduak naung ammantangmantang ri daengku. (Saya sangat ingin ke rumah kakak saya bermalam.)
B. Bajikmi punna paleng erokkonaung. (Baiklah, kalau kamu memang ingin pergi.)

(6)c. Dialog antara paman dan kemenakan ( $\mathrm{A}=$ Paman, $\mathrm{B}=$ Kemenakan $)$
A. Niyak+mako? (Kamu sudah ada?) 
B. Niak+mak. (Sudah.)

(6)d. Peserta tutur sama dengan no 6c

A. Teako aklampai punna taknyakringak! (Kamu jangan pergi sebelum saya bangun!)

B. Bajikmi. (Baiklah.)

(6)e. Peserta tutur sama dengan no $6 \mathrm{c}$
A. Sengkakirolong mae ribolaya puang nakicaricarita. (Mampir dulu, Pak, supaya kita cerita-cerita.)
B. Kammatojengi antu nukanaiya anak. (Betul sekali yang kamu katakan, Nak.)

(6)f. Peserta tutur sama dengan 6c
A. Rinnimaki bajik akbangngi ri balla puang. Batturinipaki nakinarrusu tamak ri Tombolok. (Sebaiknya menginap disini saja, Pak. Nanti dari sini Bapak langsung ke Tombolok.)
B. Tarimakasik jai dudu anak. Mangepaseng ri Mangkasarak nakubattuakbangngi ri ballaknu. Katenapoeng kupauangi andiknukana lasengka riballak+nu.
(Terima kasih banyak, Nak. Nanti kalau saya ke Makassar lagi saya ke rumahmu bermalam.)

Dialog (6a-f) juga menunjukkan pola strategi kesantunan yang sama dengan dialog (5a-c), yakni superior cenderung memilih pola sapaan yang lebih kasual, sedangkan inferior cenderung memilih pola sapaan yang lebih hormat. Suami dan paman yang superior cenderung menggunakan sapaan yang lebih kasual dibandingkan dengan istri dan kemenakan yang lebih inferior. Grafik berikut ini memaparkan rekap persentase pola strategi kesantunan data budaya etnik Makassar.

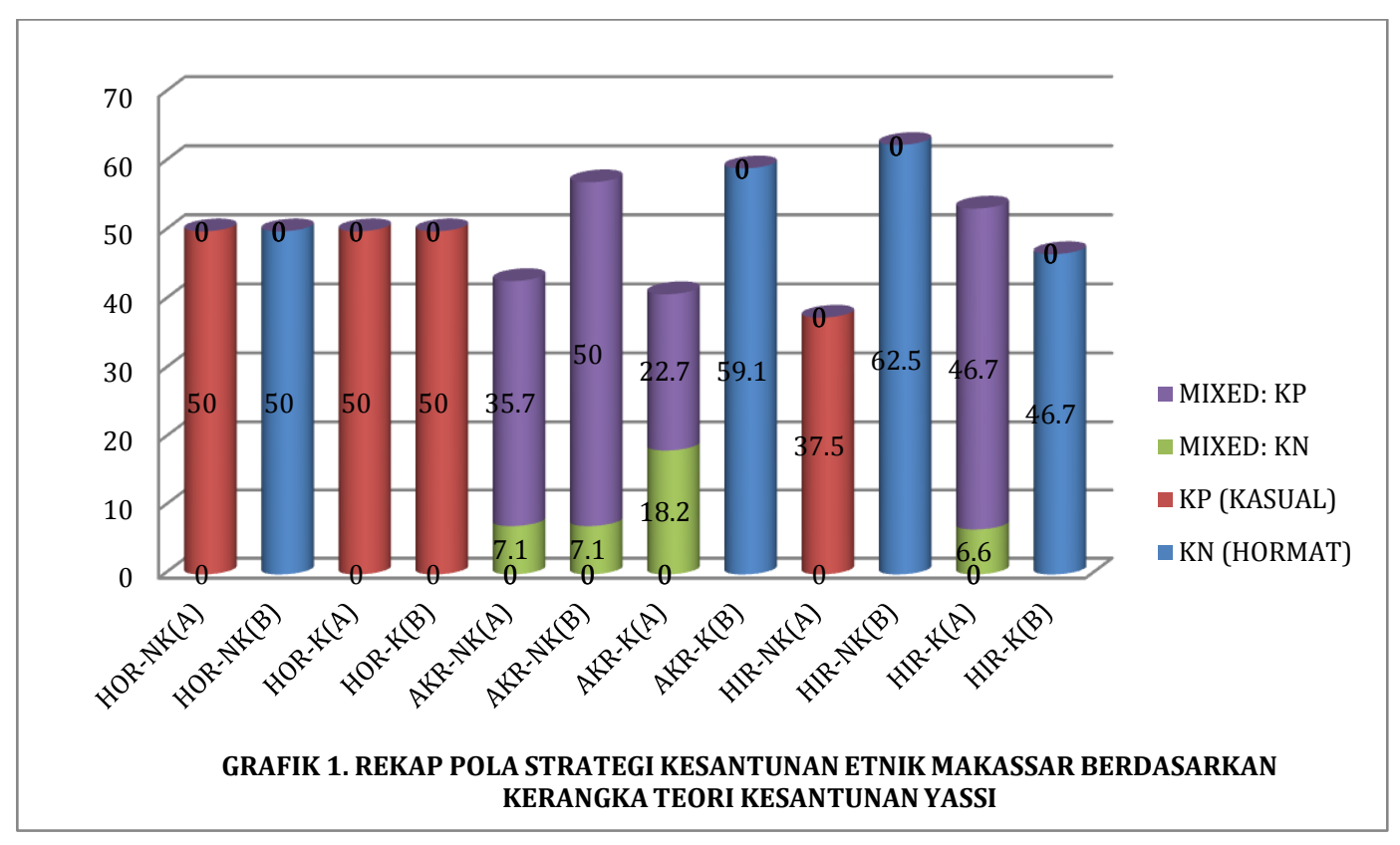




\section{Bahasa Enrekang}

1. Hormat tidak berkerabat $(-\mathrm{P},+\mathrm{D},-\mathrm{K})$

Data 7 berikut ini adalah percakapan antara dua orang yang baru bertemu (A lebih tua daripada B).

(7) A. Leppangki' (Mari singgah.)

B. Iye', makasi. (Ya, terimakasih.)

A. Inja umborako tu'u makale-kale? (Kamu mau ke mana pagi-pagi?)

B. Inja jio te'e, pasa. Deen kuanga. Maiki'. (Ke bawah sana, di pasar. Ada yang saya ingin cari. Mari. )

A. Iye'. (Ya.)

Dari percakapan di atas terlihat bahwa penutur A membuka pembicaraan dengan mengatakan leppangki', di mana imbuhan - $k i$ ' 'kamu, anda' pada kata leppangki' merupakan ciri bahasa sopan. Walaupun usia penutur A lebih tua daripada penutur B, penutur A mengawali dengan bahasa yang sopan. Secara harfiah, leppangki' bermakna 'singgah'. Di Enrekang, meskipun tidak saling kenal, ketika orang lewat di depan rumah, mereka akan memanggil untuk singgah dengan mengucapkan leppangki'. Dengan demikian, ungkapan leppangki' lebih berfungsi sebagai phatic communion daripada bentuk ajakan.

Penutur A mulai beralih menggunakan ragam yang lebih kasual ketika menuturkan umbarako? 'anda mau kemana?' di mana imbuhan -ko 'kamu' sebagai penanda ragam kasual. Hal ini dilakukan oleh penutur A setelah dia menyadari bahwa dia berusia lebih tua daripada penutur B walaupun pada akhirnya penutur A kembali menggunakan kesantunan negatif, menggunakan ragam tutur hormat setelah itu. Sebaliknya, penutur B secara konsisten menggunakan kesantunan negatif, yakni ragam bahasa sopan seperti iye' 'ya', dan maiki' 'saya pamit'. Hal ini karena usia penutur B lebih muda dibandingkan dengan penutur A.

Selain itu, faktor keakraban antara penutur A dan penutur B merupakan hal yang sangat penting dalam pemilihan ragam tutur. Kedua penutur baru bertemu dan tidak saling mengenal satu sama lain. Ketika mereka belum mengenal lawan bicara mereka, mereka cenderung akan menggunakan strategi kesantunan negatif, yakni menggunakan bahasa atau ragam sopan untuk menghargai lawan tutur mereka. Meskipun usia penutur A lebih tua, ia hanya menggunakan kata kasual sekali, yaitu umbarako, sebaliknya dia lebih banyak menggunakan bahasa yang sopan, yaitu maiki' dan iye'. Ini menandakan bahwa faktor usia dan keakraban sangat berpengaruh dalam budaya kesantunan bahasa Enrekang. Disimpulkan bahwa pola strategi kesantunan yang digunakan peserta tutur pada dialog ini adalah kesantunan negatif, yakni menggunakan ragam tutur hormat atau ragam tutur yang lebih sopan. Selebihnya adalah ragam tutur campuran antara ragam tutur hormat dan ragam tutur kasual.

2. Hormat berkerabat $(-\mathrm{P},+\mathrm{D},+\mathrm{K})$

Data (8) berikut ini adalah percakapan antara keponakan (A) dan paman (B) yang sudah lama tidak bertemu.

(8) B. Selesiramokokah pale'? (Kamu sudah selesai kuliah?)

A. Iye om, wattunna Januari. (Iya, Om, waktu Januari.)

B. Apa pale' andimmu? (Bagaimana dengan adikmu?)

A. A... massusun skripsimi goa, Om. Mettang gajamo njo tasikita le', Om. Pira pulo 
taunrameki di KL? (Sudah susun skripsi juga Om. Sudah lama kita tidak ketemu, Om. Sudah berapa puluh tahun di KL?)

B. Mettang gajamo ndi'. Deen mo kapang dua pulo taunna. (Sudah lama sekali, dik, mungkin sekitar 20 tahun.)

A. Wii.. mettang gaja tonganmo pale om le'. Iamo na mikkalaen-laen kana'ramo tu bahasa endekanta kupisa'dingi. (Benar sudah lama sekali, Om. Itu kenapa bahasa Enrekang Om sudah aneh kedengarannya.)

B. Iyamo kapang. (Itulah mungkin.)

A. Solaki pale tanta ratu? (Om datang bersama Tante?)

B. Iye, e piranna muinja Makassar si? (Ya. Kamu kapan ke Makassar lagi?)

A. Ai njomo dikussen goa te'e om sa deen unnapa kuurusu, selesaipi kapang anu, urusanku jo te'e na kuinja si Makassar. Ke njopa, torro-torroseki jolo bantu i mama. (Belum tau, Om, karena saya masih ada urusan. Mungkin kalau urusan selesai di sini baru ke Makassar. Kalau belum, saya tinggal dulu bantu mama.)

Seperti terlihat pada percakapan di atas, kedua peserta tutur menggunakan strategi kesantunan yang berbeda. Penutur A cenderung menggunakan strategi kesantunan campuran antara kesantunan positif dan kesantunan negatif, artinya kadang-kadang menggunakan ragam tutur yang kasual seperti bentuk sapaan - $k o$ 'anda, kamu', dan kadang-kadang menggunakan ragam tutur yang hormat seperti $-k i$ 'anda, kamu', dan iye 'iya'. Sebaliknya, penutur B secara konsisten menggunakan strategi kesantunan negatif hingga akhir percakapan.

Fenomena ini dimotivasi oleh hubungan sosial kedua peserta tutur. Kedua peserta tutur berkerabat jauh dan sudah lama tidak bertemu. Hal ini membuat seakan-akan peristiwa tutur tersebut dilakukan oleh dua orang yang tidak saling mengenal satu sama lain sehingga pilihan strategi kesantunan pada situasi tutur seperti itu lazimnya adalah kesantunan negatif, yakni menggunakan ragam tutur yang lebih hormat.

Disimpulkan bahwa pola strategi kesantunan yang digunakan pada dialog tersebut di atas adalah kesantunan negatif, yakni dengan menggunakan ragam tutur hormat atau sopan yang juga kadang-kadang menggunakan ragam tutur campuran antara sopan dan kasual. Dengan demikian, pada kedua pola interaksi ini, yakni hormat berkerabat dan hormat tidak berkerabat umumnya menggunakan pola strategi kesantunan negatif, yakni menggunakan ragam tutur hormat atau sopan dan campuran antara kesantunan negatif dan positif, yakni ragam hormat dan kasual.

3. Akrab tidak berkerabat (-P, $-\mathrm{D},-\mathrm{K})$

Data di bawah ini adalah percakapan antara dua teman akrab yang direkam di pasar. Usia mereka sebaya.

(9) A. E, jadimi. (Ini, sudah jadi.)

B. Ai, daumo. (Tidak usah!)

A. Ma'namo (Tidak apa-apa)

B. Daumo ah. (Ah! Tidak usah.)

A. Purami. (Tapi sudah selesai.)

B. Mettang gajako ah! (Kamu lama sekali!)

A. Apa? (Apa?)

B. Mu pa puru' - puru' kana 'ra! (Kamu cuma buat saya capek!) 


\section{A. Apa? (Apa?)}

B. Purasiko melo' teasiko, purasiko melo' teamasiko! (Setelah kamu bilang mau, tibatiba tidak mau, bilang mau lagi, tidak mau lagi!)

B. Doppapi, wappai tee akka'i jolo' tee! (Nanti! Kamu itu, angkat ini dulu!)

A. Iya tijio tau mitamba. (Tunggu, ada orang di sana memanggil.)

B. Daumo keteako. (Tidak usah kalau tidak mau.)

A. La na alli balemu tallu pulo mesa! (Dia mau membeli ikanmu 31 ribu!)

B. Napai tuu balung cakalang na masuli gaja tallu pulo mesa'? Bale pitu sa'bu ra tu'u. (Kenapa dia jual ikan cakalang dengan harga mahal, 31 ribu? Itu seperti ikan harga 7 ribu.)

A. De mi. (Berikan saja dia).

B. Mu pa pusing kana'ra'. (Kamu membuat saya pusing.)

Dialog tersebut di atas merupakan interaksi antara dua penjual ikan yang usianya sebaya yang direkam di salah satu pasar tradisional di Enrekang. Kedua peserta tutur menggunakan bentuk ragam tutur yang lebih kasual dan langsung, misalnya penggunaan butir leksikal daumo 'tidak perlu' atau 'tidak usah', dalam menegasi tanpa ditemani oleh bentuk sapaan seperti Pak/Bu, Bapak/Ibu, Puang, Daeng, Aji, dan lain sebagainya. Bentuk sapaan seperti ini dapat dikategorikan bentuk tidak sopan jika dituturkan oleh penutur yang lebih muda ke yang lebih tua. Namun, jika dituturkan antara dua orang yang akrab atau sebaya dengan status sosial yang setara maka dianggap wajar. Bahkan tuturan tersebut membuat keduanya terlihat lebih akrab. Selain itu, penggunaan suffiks $-k o$ dan $-m u$ (-ki dan butir leksikal kita sebagai bentuk sapan yang hormat) digunakan secara bergantian oleh kedua peserta tutur. Yang lain adalah penggunaan umpatan, wappai te'e, yang bermakna 'apa ini', sebagai penanda bahwa penutur merasa tidak nyaman, atau marah terhadap lawan tuturnya. Terlihat bahwa pola strategi kesantunan yang digunakan pada interaksi ini didominasi oleh kesantunan positif, yakni dengan menggunakan ragam tutur yang lebih kasual atau lebih langsung. Hal ini dimotivasi oleh pola hubungan sosial kedua peserta tutur, yakni mereka yang usianya sebaya dan merupakan teman akrab.

\section{Akrab berkerabat $(-\mathrm{P},-\mathrm{D},+\mathrm{K})$}

Data berikut ini adalah interaksi antara adik laki-laki (A) dan kakak perempuannya (K) yang direkam pada situasi tutur yang berbeda.

(10) K. Injako jolo’ alatanna wai' dinun! (Ambilkan saya minum!)

A. Doppa jolo'. (Nanti dulu!)

(11) A. Di sanako e. (Kamu ke sini!)

K. Doppa. (Nanti!)

(12) K. Sumu moko siga'. (Kamu bicara sekarang!)

A. Apa? (Apa?)

K. Sambarang. (Apa saja.)

A. Sia' ko, berapa menit? Satu menitmo nah. (Cepat! Berapa menit? Satu menit saja ya!)

K. Napasi' na satu menit? (Kenapa satu menit?)

A. Anumi! (Mulai saja!) 
K. Napai na satu menit? (Kenapa hanya satu menit?)

A. Ih, manai? Siga' ko! (Mana? Cepat!)

Seperti terlihat pada ketiga data percakapan di atas, kedua penutur menggunakan strategi kesantunan yang sama, yakni strategi kesantunan positif. Kedua penutur menggunakan bentuk sapaan yang lebih kasual dan akrab pada saat menyapa satu sama lain yang ditandai dengan penggunaan sufiks $-k o$ 'kamu, anda' (-ki bentuk sopan atau hormat). Yang lain adalah terjadinya proses penundaan permintaan atau perintah oleh kedua penutur dengan menggunakan ungkapan doppa jolo, atau doppa, yang berarti 'nanti dulu', atau 'nanti'. Pada masyarakat Enrekang dan umumnya etnik Sulawesi Selatan, penundaan perintah atau permintaan juga bisa dikategorikan sebagai penanda perilaku tidak sopan karena dianggap melakukan perlawanan terhadap perintah. Namun, konteks tetap akan menegaskan makna ungkapan tersebut sehingga bisa dinilai sebagai bentuk tidak sopan atau bentuk yang wajar, misalnya, lawan tutur sedang mengerjakan atau akan mengerjakan sesuatu yang mendesak dan tidak bisa ditunda, maka ungkapan tersebut adalah wajar.

5. Hirarkhi tidak berkerabat $(+\mathrm{P},+\mathrm{D},-\mathrm{K})$

Percakapan antara atasan (A) dan bawahan (B).

(13) A. Diumborako pale torro, Fitrah? (Kamu sebenarnya tinggal di mana, Fitrah?)

B. Jioa te'e di Batili bu. (Di sini, di Batili, bu.)

A. Kusanga yaku to Bamba ko. (Saya kira kamu orang Bamba.)

B. Ye', njo bu, jiora di Batili. (Tidak bu, saya di Batili.)

A. Mettangmako torro jotuu? (Sudah lama tinggal di sana?)

B. Ow mettang gajamo bu, pammula SD. (Sudah lama bu, dari SD.)

A. Naira pale kua joko di Bamba le'? (Siapa yang bilang kamu tinggal di Bamba ya?)

B. Ai na taen kutorro jio di Bamba bu. (Tapi saya tidak pernah tinggal di Bamba, bu.)

A. Ai njo mo kuingaran tuu nai kua. (Saya juga sudah lupa siapa yang bilang.)

Data tersebut di atas menunjukkan penggunaan secara konsisten dua strategi kesantunan yang berbeda oleh kedua peserta tutur. Penutur A yang berada pada posisi superior secara konsisten menggunakan kesantunan positif, yakni ragam tutur yang lebih kasual dan langsung sampai akhir proses pertuturan. Ini dapat terlihat dari penggunaan imbuhan - $k o$ 'kamu, anda', pada kata diumborako, mettangmako, joko dan menyebutkan nama penutur B, Fitrah, secara eksplisit pada saat menyapa lawan tuturnya. Sebaliknya, penutur B yang berada pada posisi inferior secara konsisten merespon pertanyaan-pertanyaan penutur A dengan menggunakan strategi kesantunan negatif, yakni penggunaan ragam tutur yang lebih sopan atau hormat, seperti kata sapaan $b u$. Pada pola interaksi ini ditemukan bahwa umumnya penutur menggunakan kesantunan positif bila berada pada posisi superior sementara mereka yang berada pada posisi inferior umumnya menggunakan kesantunan negatif.

6. Hirakhi berkerabat $(+\mathrm{P},+\mathrm{D},+\mathrm{K})$

Data berikut ini adalah percakapan antara Anak (A) dan Ibu (I)

(14) I. Oo Akbar, lenja na di pasa' dadau nak, tapi injako alai tu barang-barang di pasa' dau le' sa njo kukulle bawa mananni. Apalagi la nallia semangka na kabinning tu semangka. (Akbar, saya mau ke pasar nanti nak, tapi kamu ambil barang-barang di 
pasar nanti ya karena saya tidak bisa bawa semuanya. Apalagi saya mau beli semangka, semangka kan berat.)

A. Iye, doppa kualai ma'. (O ya, nanti saya ambil ma.)

I. Tapi iyana kutelponmoko dau injamoko alai le'. (Tapi, saat saya telpon nanti, kamu langsung diambil ya?)

A. Iye'. (Ya.)

(15) I. Iya tu' nasu-nasukku' Abo, puramo mannasu te' to'o. wi marasa gaja. Maballo gaja ke mukandei makula' - kula', nak. Purami kuhidangkan jio di meja.

(Abo, masakanku sudah selesai sekarang. Enak sekali. Sangat enak dimakan dalam keadaan panas. Sudah saya hidangkan di meja.)

A. Doppa sa mapanding tu' isi ke makula gaja i na dikande. (Nanti saja karena gigi bisa sakit kalau makan di saat panas sekali.)

I. Manassimi aka kua mapanding isimmu ke makula' gajai. Njo' mo na makula'. Massu' nya, bisami dikande. Masa' ga' la kucallaki' ana' sayang.

(Tentu saja gigimu sakit kalau panas sekali. Sudah tidak panas. Maksudnya, sudah bisa dimakan. Masa sih saya mau lihat kamu tersiksa, Nak.)

A. Doppa-doppa pi ma'le'. (Nanti ya, ma.)

I. Apa itajan dau? (Tunggu apa nanti?)

A. Njo'o sa makula' unnapa. (Tidak, soalnya masih panas.)

I. Allah, dikka, dikua njo' nak, masa' dikka la makula na kudeko? Maimeko kumande. (Allah, tidak, saya bilang tidak, Nak. Masa saya mau beri dalam keadaan panas? Ayo makan sini!)

Seperti terlihat pada dialog tersebut di atas, penutur I (sebagai ibu) yang berposisi sebagai superior pada interaksi ini cenderung menggunakan strategi kesantunan campuran antara kesantunan negatif dan kesantunan positif secara bergantian. Hal ini ditunjukkan oleh penggunaan butir leksikal $N a k$ 'anak' dan sufiks $-k i$ ' 'kamu', yang dikategorikan sebagai sapaan yang sopan atau hormat, sementara padanannya, sufiks - $k o$ dan $-m u$, dikategorikan sebagai sapaan akrab atau langsung dan dianggap wajar jika digunakan oleh penutur yang lebih tua ke penutur yang lebih muda asal jangan sebaliknya. Selain itu, penutur I memanggil anaknya dengan menyebut namanya secara langsung. Dalam percakapan di atas, iye 'ya' yang dituturkan oleh penutur A dikategorikan sebagai jawaban yang sopan kepada ibunya. Penutur A dalam menanggapi Penutur I menggunakan dua versi tuturan yang semuanya bermakna 'nanti'. Yang pertama adalah doppa jolo' dan yang kedua doppa-doppa pi jolo' ma' le'. Doppa jolo' dianggap sebagai bahasa langsung karena diungkapkan tanpa kata panggilan untuk ibu/mama di akhir kalimat, sementara yang kedua lebih sopan karena menggunakan ma sebagai sapaan sang anak kepada ibunya.

Pada pola interaksi ini ditemukan pula pola strategi kesantunan yang umum terjadi pada interaksi yang berpola hirarkhi di mana mereka yang berposisi sebagai superior umumnya menggunakan strategi kesantunan positif, yakni ragam tutur yang lebih kasual saat berkomunikasi dengan yang inferior yang umumnya menggunakan strategi kesantunan negatif, yakni menggunakan ragam tutur hormat pada saat berkomunikasi dengan atasan atau dengan yang lebih senior seperti kakak, orang tua, paman dan lain semacamnya dalam kerangka pola interaksi berkerabat. 
Seperti terlihat pada dialog di atas, ada pola yang berbeda yang ditunjukkan dalam interaksi di atas. Meskipun berkategori pola interaksi hirarkhi, penutur I yang superior cenderung menggunakan pola strategi kesantunan campuran antara kesantunan negatif dan kesantunan positif, dan bukan murni menggunakan kesantunan positif seperti pola interaksi hirarkhi di atas. Hal ini disebabkan oleh peran I (sebagai ibu) yang memiliki dua spektrum. Pada satu sisi, ibu sebagai superior memiliki kekuasaan atau kewenangan terhadap anak sehingga penggunaan ragam bahasa langsung atau kasual kepada anaknya merupakan fenomena yang lazim (unmarked). Pada sisi lainnya, ibu berperan sebagai model yang ideal terhadap penanaman dan pemelajaran perilaku ideal kepada anaknya termasuk salah satunya adalah memberikan edukasi tentang bertutur yang hormat atau sopan pada saat berkomunikasi dengan siapa saja. Dengan demikian, ibu harus menggunakan kesantunan negatif, penggunaan ragam bahasa yang lebih hormat atau sopan setiap berkomunikasi dengan anak-anaknya. Grafik berikut ini memaparkan secara keseluruhan pola strategi kesantunan budaya etnik Enrekang berdasarkan kerangka teori kesantunan Yassi.

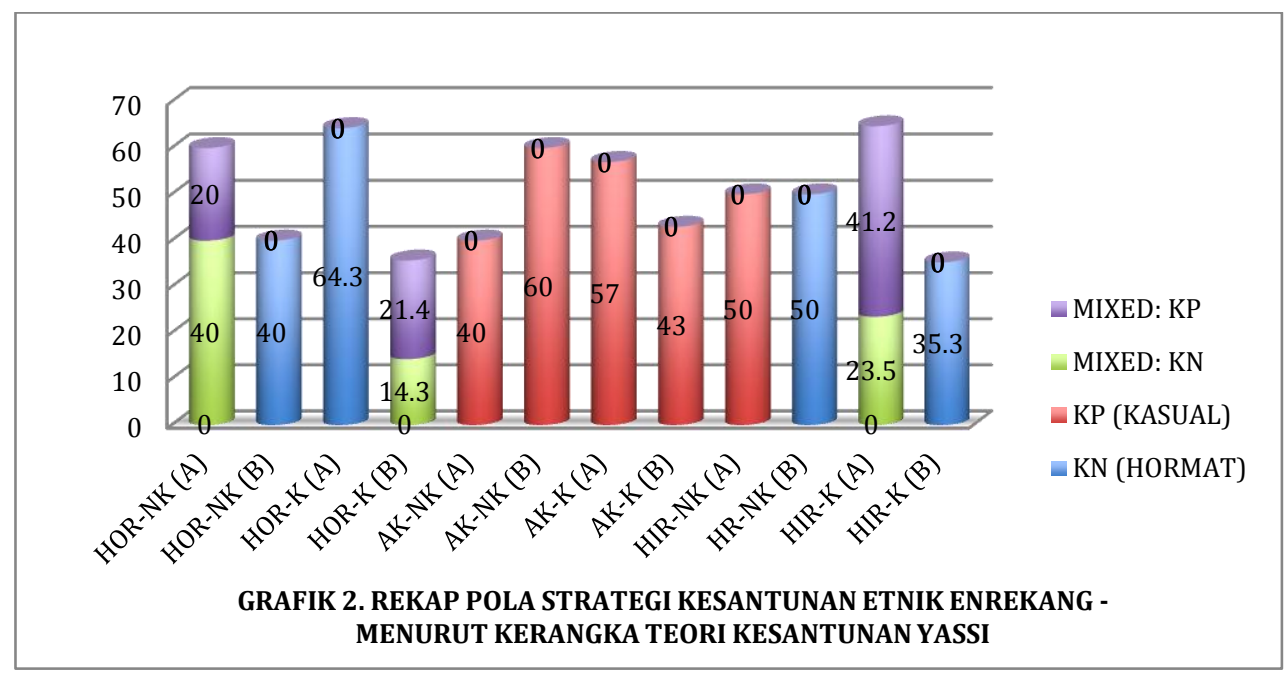

Seperti terlihat pada grafik di atas, pada pola interaksi kedua tipe hormat; tidak berkerabat dan berkerabat, seperti interaksi antara orang yang belum saling kenal, atau belum bertemu sebelumnya, atau interaksi antara kerabat jauh, pola strategi kesantunan yang digunakan pada saat berkomunikasi umumnya kesantunan negatif, yakni penggunaan ragam tutur yang hormat atau lebih sopan dan diselingi dengan campuran antara kesantunan negatif dan kesantunan positif. Sebaliknya, pada pola interaksi kedua tipe akrab - tidak berkerabat dan berkerabat - kedua peserta tutur umumnya menggunakan kesantunan positif, yakni penggunaan ragam tutur yang lebih kasual atau lebih langsung. Pada interaksi kedua tipe hirakhi - tidak berkerabat dan berkerabat - peserta tutur yang berada pada posisi superior umumnya menggunakan kesantunan positif, yakni ragam tutur yang lebih kasual sedangkan mereka yang berada pada posisi inferior umumnya menggunakan kesantunan negatif, yakni penggunaan ragam tutur yang lebih hormat. Namun, pada pola interaksi hirarkhi berkerabat, orang tua (bapak, ibu, tante, paman, kakek, nenek, dsb.) umumnya menggunakan pola kesantunan campuran antara kesantunan negatif dan positif. Penggunaan kesantunan negatif pada fenomena ini merupakan sesuatu yang marked. Artinya, karena menduduki posisi yang superior, merupakan hal yang lazim bagi orang tua untuk menggunakan kesantunan positif, tetapi pada 
fenomena ini, orang tua menggunakan juga kesantunan negatif, yakni penggunaaan ragam tutur yang hormat saat berkomunikasi dengan anak-anak mereka. Hal ini dimotivasi oleh keinginan untuk memberikan edukasi yang ideal tentang perilaku sopan kepada putra-putri mereka.

\section{Bahasa Toraja}

1. Hormat tidak berkerabat $(-\mathrm{P},+\mathrm{D},-\mathrm{K})$

Data berikut ini adalah dialog antara penjual dan pembeli, A (pembeli) and B (penjual) yang direkam di salah satu pasar tradisonal di Toraja.

(16) A. Sipira raka balemu? (Berapa harga ikanmu?)

B. Tallung pulo misa kilo. (30 ribu per kg.)

A. Masuli' maro' ia. (Itu mahal sekali.)

B. Pira la miala, tanta? (Berapa yang akan Anda ambil, Tante?)

Seperti terlihat pada dialog tersebut di atas, kedua peserta tutur menggunakan strategi kesantunan yang berbeda. Penutur A cenderung menggunakan strategi kesantunan positif, penggunaan ragam tutur yang lebih kasual yang ditandai dengan penggunaan sufiks berarti 'kamu, anda', pada kalimat sipira raka balemu? 'berapakah harga ikanmu?' Penggunaan imbuhan - $m u$ pada kalimat tersebut merujuk ke bentuk orang kedua tunggal yang bentuknya lebih kasual dibandingkan dengan sufiks $-m i$ yang lebih sopan atau hormat. Kecenderungan pembeli menggunakan ragam tutur yang lebih kasual atau langsung pada konteks ini dimotivasi oleh faktor status sosial antarpeserta tutur. Penutur A memiliki kelas sosial yang lebih tinggi dibandingkan dengan penutur B. Sebaliknya, penutur B cenderung menggunakan bentuk tuturan yang lebih hormat. Hal ini ditunjukkan oleh penggunaan prefiks mi- dan butir leksikal tanta pada kalimat pira la miala tanta 'berapakah yang mau diambil, Bu?' Penggunaan prefix mi- merujuk kepada bentuk orang kedua tunggal yang berpadanan dengan prefix $m u$ - yang lebih kasual. Butir leksikal tanta adalah bentuk sapaan hormat yang ditujukan kepada orang yang usianya lebih tua yang secara harafiah berarti 'tante', tetapi dalam konteks ini, tanta adalah bentuk sapaan yang setara dengan $b u$ 'ibu' yang umumnya digunakan kepada wanita yang usianya lebih tua.

2. Hormat Berkerabat $(-\mathrm{P},+\mathrm{D},+\mathrm{K})$

Data berikut ini adalah dialog antara dua kerabat yang baru bertemu setelah sekian lama tidak bertemu.

(17) A. Umbara kani mu ni ma' kuliah inde mangkasa'? (Kamu kuliah di mana di sini, di Makassar?)

B. Anu..yong UKIP (Di UKIP)

A. Na umba mu nai torro? (Dan di mana kamu tinggal?)

B. Yong tello. Na iko umba mu nai ma'kulia? (Tello. Dan kamu. Di mana kamu kuliah?)

A. Yongna' UNHAS. (Di UNHAS.)

B. Solako torro loren le'? (Kamu tinggal dengan Loren, kan?)

A. Iyo torrona' sola Loren. (Ya, saya tinggal dengan dia.)

Peristiwa tutur di atas terjadi antara dua kerabat seusia yang masing-masing masih kuliah dan sudah lama tidak bertemu. Kedua penutur tersebut tidak menggunakan sama sekali 
kata sapaan seperti kak, dek, dan lain semacamnya. Hal ini karena penggunaan sapaan seperti itu dalam budaya Toraja sangat jarang dilakukan. Berbeda dari budaya lain, seperti budaya Bugis dan Makassar, penggunaan bentuk sapaan yang merujuk pada kakak atau adik merupakan sesuatu hal yang lazim atau unmarked.

Meskipun sekian lama tidak bertemu, penutur A dan penutur B terlihat akrab. Hal ini terlihat dari penggunaan ragam tutur yang lebih kasual oleh kedua peserta tutur, seperti bentuk sapaan yang menggunakan prefix $m u$-, butir leksikal $i k o$, dan sufiks $-k o$ yang berarti 'kamu', atau 'anda'. Butir leksikal iyo 'ya' sangat lazim dituturkan dalam masyarakat Toraja. Kata tersebut dapat dikategorikan sopan atau tidak sopan, bergantung pada intonasinya. Intonasi yang rendah menunjukkan bahwa sapaan tersebut lebih sopan, sedangkan intonasi yang tinggi menunjukkan bahwa sapaan tersebut lebih kasual. Selain itu, bentuk sapaan $m u$, iko, dan ko 'kamu, anda' dianggap tidak sopan atau tidak hormat apabila dituturkan oleh penutur yang usianya lebih muda daripada mitra tuturnya, atau dituturkan oleh rakyat jelata kepada keturunan bangsawan, atau bawahan kepada atasannya. Umumnya bentuk sapaan ini digunakan oleh peserta tutur yang usianya sebaya atau berkerabat yang fungsinya untuk menghindari kekakuan antara peserta tutur. Namun, pada umumnya peserta tutur akan menggunakan ragam tutur sopan jika lawan bicara berumur jauh lebih tua seperti pada percakapan berikut:

Percakapan antara dua kerabat jauh yang menggunakan bahasa hormat/sopan:

(18) A. Iyo tau yo lu. (Ya, orang di sana.)

B. Tau Cianjur? (Orang Cianjur?)

A. Iyo. (Ya.)

B. Pa'kampung yo ia liu. (Dia orang asli di sana?)

A. Iyo tau yo ialu. (Ia asli orang di sana.)

B. Morai sia duka mi tampe yo mai le'. Biasa sia sae. (Apa dia mau Anda tinggalkan, apa dia pernah ke sini?)

A. Tae' na sae len. (Tidak pernah.)

B. Tomatua miki' tae' mo la sule rekke. (Kita sudah tua tidak mau ke kampung lagi.)

Dari dialog di atas terlihat bahwa kedua peserta tutur menggunakan sapaan dengan bentuk prefiks $m i$ - 'anda, kamu' yang dikategorikan sebagai ragam tutur sopan. Meskipun berkerabat, usia peserta tutur pada dialog di atas sudah dewasa. Hal inilah yang menyebabkan interaksi tersebut cenderung lebih menggunakan strategi kesantunan negatif, yakni ragam tutur yang lebih sopan atau hormat.

3. Akrab tidak berkerabat (-P,-D,-K)

Percakapan antara dua teman akrab melalui telepon.

(19) A. Haloo. (Halo)

B. Haloo. (Halo.)

A. Pekapuai gamarammu, Tan. (Besarkan suaramu, Tan.)

B. Halooooo. (Halo.)

A. Iyooooo. Mamma' ko? (Ya, kamu tidur?)

B. Iyo..millikmo'. (Ya.. saya baru bangun.)

A. Ooo..inda musolan iti'? (Ooo.. kamu sama siapa?)

B. Sola na' batto'. (Dengan batto'.)

A. Inda? (Siapa?) 
B. Batto'.. Tan? (Batto'... Tan?)

A. Apa? (Apa?)

B. Lamale roko kamai? (Kamu mau ke sini?)

A. Dako' pi. (Nanti.)

Peristiwa tutur di atas dilakukan antara dua orang sahabat yang seusia. Dengan demikian, kedua peserta tutur cenderung menggunakan pola strategi kesantunan positif pada saat berkomunikasi, yakni penggunaan ragam tutur yang lebih kasual seperti penggunaan sufiks - ти dan - ko untuk orang kedua tunggal seperti pada tuturan pekapuai gamarammu tan dan iyooooo. Mamma' ko? dan bukan $-m i$ dan $-k i$ yang lebih hormat. Selain itu, penyebutan nama lawan tutur secara eksplisit juga menunjukkan kasualitas pertuturan tersebut di atas.

\section{Akrab Berkerabat $(-\mathrm{P},-\mathrm{D},+\mathrm{K})$}

Percakapan antara dua orang saudara kandung. A (adik perempuan) dan B (kakak perempuan).

(20) A. Mangngapa ko? (Kamu sedang apa?)

B. Mangngapa o ... menonton (Tidak ada, hanya menonton.)

A. Nainda musolan iti' banua (Dengan siapa kamu di rumah?)

B. Kami manda kami sola tallu e. ooo.tae' pa ku patama perpuluhanmu. Male langngan tilangnga' tau ma'gereja. (Hanya kami bertiga. Saya belum kumpul perpuluhanmu. Orang-orang ke Tilangnga' beribadah.)

A. Dadi tae' $\boldsymbol{m u}$ ma' gereja pull allo? (Jadi kamu tidak pergi beribadah seharian?)

B. Tae' ..ma'gereja ditilangnga' nakua ma' Rati sangmai ke Tilangnga' kaykanya orang gereja. (Tidak, orang pergi ke gereja kata Mamanya Rati kemarin di Tilangnga', ke Tilangnga' kemungkinan orang pergi ke gereja.)

A. Tae' pa raka karebanna piran na kawin anakna mama Tian? (Kamu tahu kapan anaknya tante mama Tian menikah?)

B. Tae'para, tae'bangpara tau sae metamba. Nakusanga iko pokada tanggala' karua. (Belum, belum ada yang datang mengundang. Saya pikir kamu bilang tanggal 8.)

A. Ah.. tanggala 'karua lai' Nurul ia la kawin. (Tidak, Nurul yang akan menikah tanggal 8.)

Pola strategi kesantunan yang digunakan oleh kedua peserta tutur pada peristiwa tutur di atas adalah kesantunan positif yakni penggunaan ragam tutur yang lebih kasual atau lebih langsung. Meskipun usia penutur A jauh lebih muda dari penutur B, keakraban keduanya tergambarkan dengan penggunaan bahasa kasual seperti penggunaan sufiks - $k o$ yang berarti kamu pada mangngapa ko? dan sufiks - $m u$ 'kamu' pada musolan, serta prefix mu- 'kamu' pada kalimat dadi tae' ти ma' gereja pull allo. Hal ini juga senada dengan penutur B yang menggunakan ragam tutur yang lebih kasual seperti iko 'kamu' pada kalimat nakusanga iko pokada tanggala' karua.

Dalam budaya Toraja, penutur yang lebih muda seharusnya menggunakan bentuk sapaan yang lebih hormat ketika menyapa lawan tutur yang lebih tua. Akan tetapi, jika ia telah menikah, ia diperbolehkan memanggil nama orang tersebut jika usianya tidak terpaut jauh.

5. Hirarkhi tidak berkerabat $(+\mathrm{P},+\mathrm{D},-\mathrm{K})$

Data di bawah ini adalah percakapan antara senior dan junior, A (Junior) dan B (Senior).

(21) A. Mangkamo tugas mi kak? (Apakah tugas Anda sudah selesai, kak?) 
B. Aeh tae'pa tae' tandai umbanna laku jama dolo'. (Belum, saya tidak tahu yang mana yang harus saya kerjakan terlebih dahulu.)

A. Taebang pa mui CCC? (Tidak ada, bahkan CCC?)

B. Iyo CCC raka SFG raka taepa. Pusingna' tedaka' tau indaraka laku jadikan partisipan. ma' bahasa indonesia nasangmo taula. Tae' mona ma' basa Toraya. Yake kamu mangkamo roko ka? (Iya, CCC ataupun SFG belum. Saya pusing mencari orang untuk dijadikan partisipan karena semua orang sepertinya sudah menggunakan bahasa Indonesia. Sudah tidak ada lagi yang menggunakan bahasa Toraja. Kamu bagaimana?)

A. Tae' duka pa ah. (Belum selesai juga.)

Pola strategi kesantunan yang digunakan oleh kedua peserta tutur di atas berbeda satu dengan lainnya. Terlihat bahwa penutur A yang lebih yunior cenderung menggunakan strategi kesantunan negatif, yakni penggunaan ragam tutur yang lebih hormat seperti bentuk sapaan sufiks - $m i$ 'kamu' dan butir leksikal kak 'kakak', sementara penutur B yang lebih senior cenderung menggunakan strategi kesantunan positif, yakni penggunaan ragam tutur yang lebih kasual seperti bentuk sapaan sufiks - $k o$ 'kamu, anda'. Bentuk sapaan kamu yang dituturkan oleh B merupakan bentuk sapaan yang netral atau wajar di mana bentuk ini tergolong ragam tutur yang kasual pada budaya lain seperti Bugis dan Makassar.

6. Hirarkhi Berkerabat $(+\mathrm{P},-\mathrm{D},+\mathrm{K})$

Data berikut ini merupakan percakapan lewat telepon antara ibu (A) dan anak perempuannya (B).

(22) B. Haloo.. mangngapa komi ma? (Haloo.. mama lagi bikin apa?)

A. Aeehh.indesiana' sidua lai' Tatum. (Saya dengan Tatum.) Umbara ro ko ni? (Kamu di mana?)

B. Inde na' kosan. (Saya di kosan.)

A. Mangngapako? (Kamu sedang apa?)

B. Tae'ra.. mangngapao. (Tidak apa.)

A. Kua mbai tassu omo ko. (Saya pikir kamu keluar lagi.)

Pola strategi kesantunan yang digunakan oleh kedua peserta tutur pada pola interaksi ini berbeda satu dengan lainnya. Penutur B, yang berada pada posisi yang superior, cenderung menggunakan strategi kesantunan positif yakni ragam tutur yang lebih kasual seperti bentuk sapaan sufiks - $k o$ 'kamu, anda', sementara penutur A, sebagai anak yang berada pada posisi inferior, cenderung menggunakan strategi kesantunan negatif, yakni ragam tutur yang lebih hormat seperti bentuk sapaan komi 'kamu, anda'.

Grafik berikut ini menunjukkan pola strategi kesantunan yang digunakan oleh kedua peserta tutur pada interaksi hubungan sosial seperti tersebut di atas. 


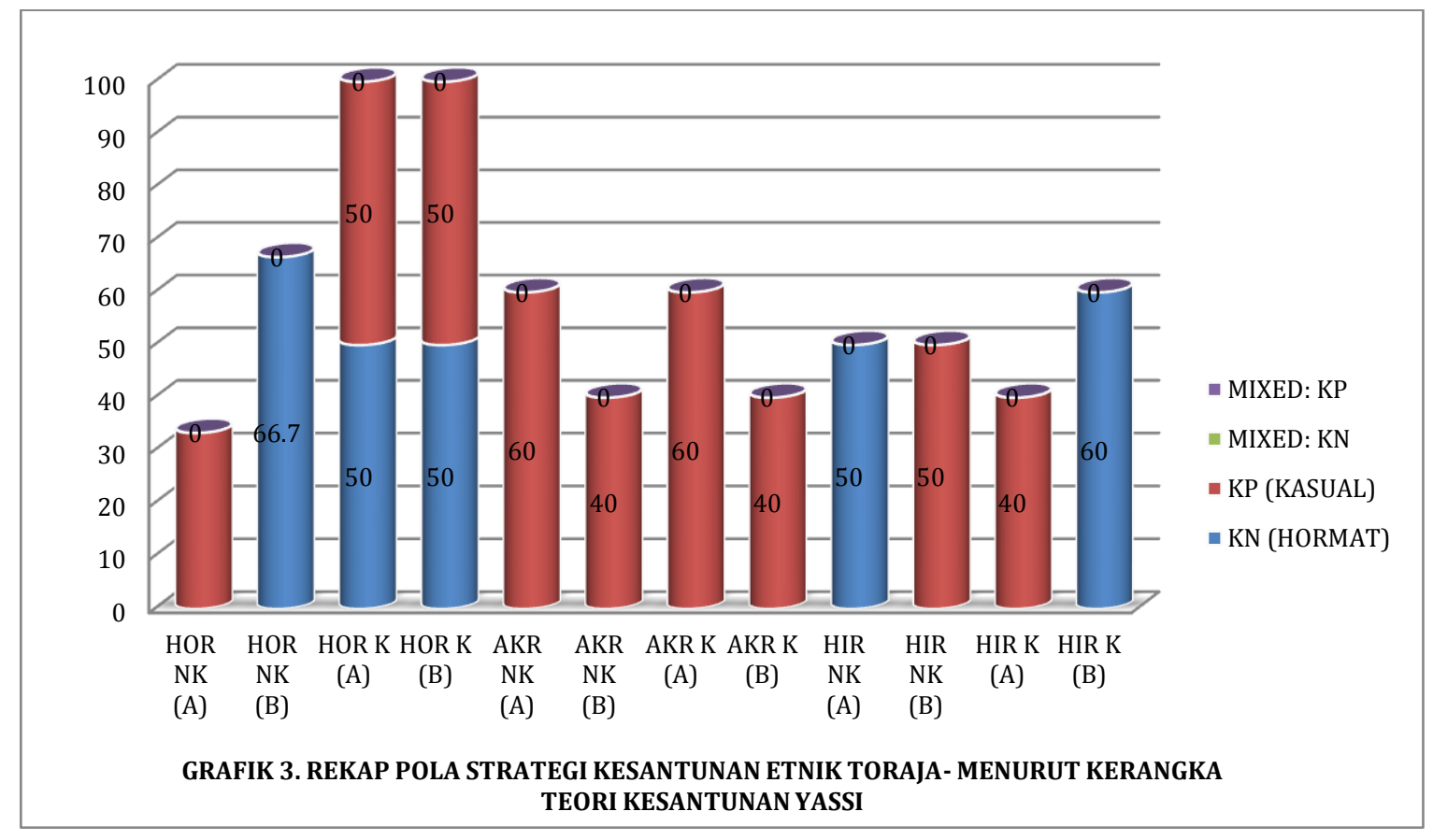

\section{Bahasa Tae' Palopo}

1. Hormat tidak berkerabat $(-\mathrm{P}+\mathrm{D}-\mathrm{K})$

Data berikut ini adalah percakapan antara dua orang yang belum kenal dan belum pernah bertemu sebelumnya.
A. Menna te'e? (Siapa ini?)
B. Ee, Rais kita'?. (Rais, Anda.)
A. Oh, Rais. Aku Andisa, Solana Caling. (Oh Rais, saya Andisa, teman Caling.)
B. Oh, Solana Caling. Mapai kita? (Oh, teman Caling, ada apa?)

A. Tae'ra.. laku kutanai ki. (Tidak, cuma ingin bertanya.)

B. Ohiye. (Oh iya.)

A. Umba ta ngei torro? (Tinggal di mana?)

B. Oh inde kita anu... Baebunta. (Oh di anu... Baebunta)

A. Oh, Baebunta? Seletting ki Caling? (Oh, Baebunta, kamu seangkatan dengan Caling?)

B. Iye, tae' kita. Kakak kelasku itu. (Tidak, dia kakak kelas saya.)

A. SMA baebuntaki yolo kah? (Dulu SMA di Baebuntakah?)

B. Iye, dio kita SMA baebunta iye (Ya, di SMA Baebunta.)

A. Masai mo tatandai tu uwak caling? (Sudah lama kenal dengan Caling?)

B. Ai masai mo kita, den mo uиu.. ma'taung mo. (Ai sudah lama, sudah uuu...sudah bertahun-tahun).
A. Ma'taung mo. (O sudah bertahun-tahun.)
B. Iye. (Ya.)
A. Na umba kita dingei torro raka? (Kalau kamu tinggal di mana?)
B. Dio na' Makassar (Saya (tinggal) di Makassar)
A. Oh, apa I jama dio Makassar? (Oh, bikin (kerja) apa di Makassar?)
B. Makulia na. (Saya kuliah.) 


\section{A. Umba na ngei? (Di mana?) \\ B. Dio na Unhas. (Di Unhas.)}

Percakapan di atas menunjukkan hubungan simetris yang saling menghormati satu dengan lainnya. Penggunaan morfem ki, kita, iye dan imbuhan ta menjadi pemarkah kesantunan untuk menyapa lawan tutur. Adapun kata kita dalam percakapan tersebut berfungsi dan bermakna ganda. Pertama, dapat digunakan sebagai sapaan untuk persona kedua tunggal atau lawan bicara yang bermakna kamu. Selain itu, juga dapat berfungsi sebagai pemarkah kesantunan yang disematkan di akhir kalimat, tetapi tidak memiliki arti secara harfiah. Begitu pula dengan penggunaan kata iye, selain berfungsi sebagai bentuk tanda setuju, juga sebagai penanda bentuk santun dalam berbicara. Ragam bahasa ini tidak berlaku secara keseluruhan pada Bahasa Tae', tetapi lebih sering digunakan oleh komunitas bahasa Tae' di Luwu bagian utara dan timur. Selain itu, meskipun keduanya berusia sebaya, kedua penutur tersebut tetap menggunakan tuturan yang sopan. Dengan demikian, pola strategi kesantunan yang digunakan pada dialog tersebut di atas adalah kesantunan negatif, yakni pengggunaan ragam tutur hormat atau sopan.

2. Hormat berkerabat $(-\mathrm{P}+\mathrm{D}+\mathrm{K})$

Data berikut ini adalah percakapan antara dua orang yang berkerabat jauh dan jarang bertemu.

(24) A. Na ... piran mi ratu? (O.. kapan datang?)

B. A sangmai. (Kemarin.)

A. Mmm menna misolan jomai? (Mmm dengan siapa datang ke sini?)

B. Anu..sola na mama' ku na? (Anu, dengan ibu saya)

A. Ooo den raka urusan inde la dijama? (Oo.. ada urusankah di sini mau diselesaikan?)

B. A tae, masaki-saki tu nenek inde na, nakuanna mama ku male ko solanna rokko kampong jolo (A tidak, nenek di sini sakit-sakitan, jadi ibu saya bilang temani saya ke kampung.)

A. Ooh pantasan maneku untiro ki inde kampong na. (Ooh pantas saya baru lihat di sini, kampung)

B. Jio bang $\boldsymbol{k i}$ anu te ah.. kampong na tau jaka dalle. (Lagi di kampung orang sekarang cari berkah.)

A. Ooh, ko umba mingei totemo raka? (Ooh, jadi di mana sekarang (berdomisili)?)

B. Aii jio bangsia mangkasa tu. (Di Makassar aja.)

A. Mmm... dulu sekolah di Baebunta kah? (Mmm... dulu sekolah di Baeuntakah?)

B. Nakita iya, apa mijama inde mai? (Kalau kamu bikin apa di sini?)

A. Ah tae, anu. Torro jagai kampong hehe, male ma' bela (Ah tidak, anu, tinggal jaga kampung hehehe, pergi berkebun.)

Percakapan di atas menunjukkan fenomena yang berbeda dari B\&L (marked). Meskipun berkerabat, kedua peserta tutur cenderung menggunakan pola strategi kesantunan negatif, yakni penggunaan ragam tutur hormat atau sopan, seperti penggunaan bentuk sapaan mi-, misolan, ki, mingei, nakita, mi, miki, ta, ta, ki, tabe, dan iye'. Situasi marked lainnya adalah kedua peserta tutur memiliki usia yang sebaya tetapi mereka dengan konsisten menggunakan strategi kesantunan negatif sebagaimana pada ujaran dulu sekolah di Baebuntakah?, keduanya tetap bertutur secara sopan. 


\section{Akrab non-Kerabat $(-\mathrm{P}-\mathrm{D}-\mathrm{K})$}

Data berikut ini merupakan percakapan antara teman yang sudah saling kenal dan akrab. Percakapan ini berlangsung di teras rumah A.

A. Umba lamuaola Ical? (Mau ke mana, Ical?)

B. Inde tu lako. (Ke sana.)

A. Apamuala? (Bikin apa?)

B. Manjo ma olahraga. (Pergi berolahraga.)

A. Sore-sore olahraga e? (Sore-sore olahraga)

B. Iyo, susi memang to, diparokko-rokko kale ta ... naiko, umba mungei sule? (Ya, begitu memang, menurunkan berat badan .... Kalau kamu, dari mana?)

A. Ah inde' ... sule ma'pa'guru. (Ah di sini... dari mengajar.)

B. Umba mungei ma'pa' guru memang na? (Mengajar di mana memang?)

A. Jio anu, SD 16. (Ai anu, SD 16.)

B. Ah na karuen maro' musule? (Ah kenapa terlalu sore pulang?)

A. Anи ... susimo to ke anu omi tu pa ... (Anu... sudah begitu memang kalau lagi anu pa...)

Percakapan di atas menunjukkan pola percakapan yang simetri atau setara. Kedua peserta tutur menggunakan pola strategi kesantunan positif, yakni penggunaan ragam tutur yang lebih kasual atau lebih langsung seperti penggunaan imbuhan $m u$, kata $i k o$, kata iyo dan penyebutan nama secara langsung (Ical). Selain itu, status penutur B sebagai seorang guru tidak mempengaruhi bahasa yang digunakan dari penutur A. Penutur A menggunakan bentuk sapaan $m и$ atau bentuk kata ganti orang kedua tunggal untuk merujuk pada penutur B. Situasi tutur yang informal juga berkontribusi terhadap pola pilihan ragam tutur yang lebih kasual oleh kedua peserta tutur. Selain itu, faktor lain yang juga berkontribusi terhadap fenomena pilihan ragam tutur seperti itu adalah usia, yakni keduanya sebaya dan bahkan telah saling kenal lama dan sangat akrab.

\section{Akrab Berkerabat $(-\mathrm{P}-\mathrm{D}+\mathrm{K})$}

Data di bawah ini merupakan percakapan antara dua orang yang memiliki hubungan kekerabatan. Percakapan tersebut dilakukan melalui telepon.

B. Menna musolan iti raka? (Dengan siapa di situ?)

A. Menna? (Siapa?)

B. Menna musolan iti? (Dengan siapa di situ?)

A. Iwang. (Iwang.)

B. Iwang... menna sia musolan iti, iwan ri sola....? (Iwang... siapa saja di situ yang kamu temani, hanya Iwang dengan...?

A. Sola dua na. (Berdua.)

B. Oh sola dua rako? (Oh, kamu cuma berdua?)

A. $\operatorname{Mmm}(\mathrm{mmmm})$

B. Ah eh na ama-jama tongan omo komupea (Ah eh saya benar-benar lagi dikerjai.)

A. (tertawa)... umba mungei te? (Kamu di mana ini?)

B. Inde bang sia na Pinrang. (Masih di sini, Pinrang.)

A. Oh kusanga umbai jao moko Makassar (Oh, saya kira kamu sudah di Makassar.) 
B. Sule na jao mai appa tae na anu di ... apa sanganna.... (Saya pulang ke sini karena tidak anu di... apa.... )

A. Apa? (Apa?)

B. Tae dingei jao anu na... (Tidak ada tempat di sana untuk anu na...)

Strategi kesantunan yang cenderung digunakan oleh peserta tutur pada percakapan di atas adalah strategi kesantunan positif, yakni penggunaan ragam tutur yang lebih kasual atau langsung, seperti penggunaan $m u$-, -ko serta komи yang merujuk kepada persona kedua tunggal, kamu, juga penggunaan kata pea untuk menyapa lawan tutur, yang arti harfiahnya adalah 'anakanak'. Fenomena pilihan strategi kesantunan seperti itu dimotivasi oleh faktor usia, di mana usia kedua peserta tutur relatif sama. Selain itu, faktor kekerabatan juga berkontribusi positif terhadap pilihan strategi kesantunan oleh peserta tutur.

5. Hirakhi tidak berkerabat $(+\mathrm{P}+\mathrm{D}-\mathrm{K})$

Data di bawah ini adalah percakapan antara atasan dan bawahan di tempat kerja pada jam istirahat.

A. Pura na mantarima gaji ... e solanni sola mangka ke anu le... (Saya sudah terima gaji... e kamu temani dia nanti kalau anu ya...)

B. Apa? (apa?)

A. Pura le...sola ko le ke wattu mantarima mangka. (Nanti ya... sama kamu ya pada saat terima gaji nanti.)

B. Mantarima langsung pa le? (Masih terima langsung ya?)

A. Mantarima langsung pa iya. (Masih terima langsung memang.)

B. Ooo...

A. Ke denni anummi ... ATM BRI. (Kalau kalian punya anu...ATM BRI.)

B. Аnи eе.. BCA ka ATMmi? (Anu ee... BCA kah ATMmu?)

A. BCA. (BCA.)

B. Rata-rata memang ke anu BCA. (Rata-rata memang kalau anu BCA.)

A. Mupatama saldo seratus ribu buka anu ... rekening atau ATM. (Kamu masukkan (setor) saldo seratus ribu untuk buka anu... rekening atau ATM.)

B. Rekening. (Rekening.)

A. Yang penting BRI, tae masalah. (Yang penting BRI, tidak masalah.)

B. Tae duka masalah. (Tidak masalah juga.)

Percakapan di atas menunjukkan pilihan strategi kesantunan yang berbeda antara peserta tutur. Penutur A, sebagai atasan B, memiliki power atas B sehingga pola strategi kesantunan yang digunakan adalah kesantunan positif, yakni penggunaan ragam tutur yang lebih kasual atau lebih langsung, seperti saat memberikan instruksi kepada B dengan menggunakan imbuhan -ko. Sebaliknya, penutur B, sebagai bawahan tidak memiliki pilihan alternatif bentuk ragam tutur lainnya, kecuali ragam tutur yang lebih hormat saat berkomunikasi dengan atasan dia, seperti penggunaan prefix mi- 'anda, kamu'. Fenomena ini adalah unmarked, yakni lazim. Namun, kadang-kadang penutur B menggunakan kata-kata yang bernuansa kasual seperti apa? dengan intonasi meninggi, atau dengan mendehem saja, $\mathrm{mmm}$, pada saat merespon A. Fenomena ini dimotivasi oleh hubungan kedua peserta tutur yang sangat akrab dan situasi tutur pada saat itu yang lebih kasual karena sedang beristirahat. 
6. Hirakhi Berkerabat $(+\mathrm{P}+\mathrm{D}+\mathrm{K})$

Data berikut ini adalah percakapan antara anak dan bapak melalui telepon, A anak, B Bapak.

(28)

A. Apa o pengarunna to le? (Apa pengaruhnya itu?)

B. Aaa?

A. Kua apa o pengarunna to? (Apa pengaruhnya itu?)

B. Apa? (Apa/yang mana?)

A. To'o si'du-si'du? (Itu, cegukan?) ...

A. Tae' mi pekutananni ngina? (Tidak ditanyakan tadi?)

B. Aaa?

A. Tae' mi pekutananni ngina? (Tidak ditanyakan tadi?)

B. Ah na tandai iya, kan den to petugasna, anu na cata' bang ri na den keluhan ku natiro. (Ah dia sudah tau, kan petugasnya sudah ada, anu dia tinggal catat saja kemudian ada keluhan saya yang dia lihat.)...

A. Jioko Pinrang? (Kamu di Pinrang?)

A. Inde' na makassar, mane lattu' na to. Ngina makale ku lu jiong mai (Saya di Makassar, baru saja tiba. Saya berangkat tadi pagi dari sana)

B. Ooh... o mane rampoko iti Makassar? (Ooh.... Kamu baru tiba di Makassar?)

A. Iya (ya)

B. Na iya tu urusammu? (Bagaimana dengan urusanmu?)

Dialog di atas menunjukkan pola penggunaan strategi kesantunan yang berbeda oleh peserta tutur. Penutur A, sebagai anak menduduki posisi yang inferior, secara unmarked menggunakan kesantunan negatif yakni penggunaan ragam tutur yang hormat dalam jawaban kepada B, misalnya, dengan bentuk sapaan $m i$ 'anda'. Sebaliknya B, sebagai ayah menduduki posisi yang superior, cenderung menggunakan strategi kesantunan positif, seperti bentuk sapaan jioko, rampoko, urusammu 'kamu'. Grafik berikut ini menunjukkan rekapitulasi pola strategi kesantunan etnik Tae Palopo menurut kerangka teori kesantunan Yassi.

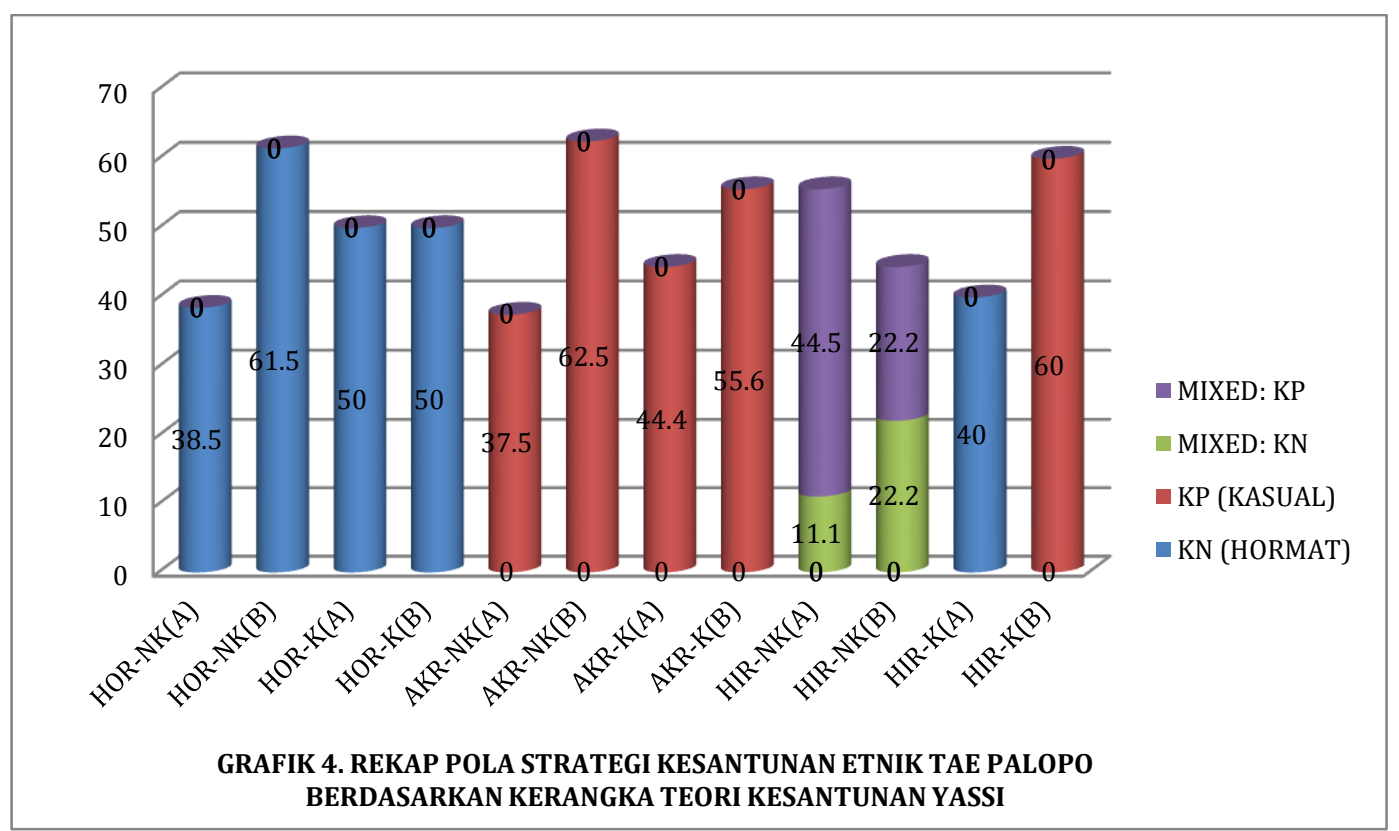




\section{PEMBAHASAN}

Seperti terlihat pada uraian diatas, pola strategi kesantunan yang digunakan oleh peserta tutur pada umumnya dapat dikatakan termasuk "unmarked phenomenon" atau lazim. Pada interaksi yang dilakukan antara peserta tutur yang tidak saling mengenal atau berkerabat jauh dan tidak terlalu akrab pola strategi kesantunan, yang umumnya digunakan adalah kesantunan negatif, yakni penggunaan ragam tutur yang lebih hormat atau lebih sopan. Hal ini terlihat pada interaksi kategori hormat non-kerabat dan hormat berkerabat.

Sebaliknya, pada interaksi yang dilakukan antara peserta tutur yang memiliki hubungan sosial yang dekat, misalnya teman akrab, strategi kesantunan yang umum mereka gunakan adalah kesantunan positif, yakni penggunaan ragam tutur yang lebih kasual, atau lebih langsung. Demikian pula pada interaksi yang berkategori hirarkhi, peserta tutur yang menempati posisi superior umumnya menggunakan kesantunan positif, yakni penggunaan ragam tutur yang lebih kasual atau lebih langsung pada saat berkomunikasi dengan inferior mereka. Sebaliknya, peserta tutur yang menempati posisi inferior umumnya menggunakan kesantunan negatif, yakni penggunaan ragam tutur yang lebih hormat atau lebih sopan pada saat berkomunikasi dengan superior mereka.

Namun, beberapa data tersebut di atas juga menunjukkan adanya beberapa fenomena yang tidak lazim (marked) atau berbeda dari kacamata kerangka teori kesantunan B\&L. Pada tataran simetri, pada interaksi Hormat tidak berkerabat pada data budaya Bahasa Makassar, salah seorang peserta tutur secara konsisten menggunakan strategi kesantunan positif yang secara "unmarked" seharusnya dia menggunakan kesantunan negatif karena mereka tidak saling mengenal dan baru bertemu saat itu. Selanjutnya, pada interaksi Akrab baik pada tataran tidak berkerabat maupun tataran berkerabat, peserta tutur menggunakan strategi kesantunan campuran antara kesantunan negatif dan kesantunan positif yang seyogianya mereka menggunakan kesantunan positif karena mereka sudah saling mengenal satu sama lain dan akrab.

Pada interaksi yang asimetri atau tidak setara khususnya pada interaksi hirarkhi tidak berkerabat, kedua peserta tutur baik yang menempati posisi superior maupun yang menempati posisi inferior menggunakan strategi kesantunan campuran antara kesantunan negatif dan kesantunan positif. Penutur yang berposisi superior yang memiliki hak istimewa untuk menggunakan kesantunan positif juga terlihat menggunakan strategi kesantunan negatif pada saat berkomunikasi dengan inferior mereka. Demikian pula terhadap penutur yang menempati posisi inferior, seyogianya mereka menggunakan kesantunan negatif, yakni penggunaan ragam tutur yang lebih hormat atau sopan, pada saat bertutur kepada superior mereka. Ternyata, mereka juga kadang-kadang menggunakan kesantunan positif yakni ragam tutur yang lebih kasual atau lebih langsung pada saat berkomunikasi dengan atasannya. Terakhir dan yang paling signifikan adalah interaksi antara suami dan istri. Pada kerangka teori B\&L, interaksi antara suami dan istri berkategori Akrab, sehingga strategi kesantunan yang mereka pilih adalah kesantunan positif. Hal ini terbantah pada data ini. Data menunjukkan bahwa interaksi antara suami dan istri berpola hirarkhi di mana suami menempati posisi superior sehingga cenderung menggunakan kesantunan positif ataupun campuran antara kesantunan positif dan negatif. Sebaliknya, istri menempati posisi inferior, sehingga mengharuskan mereka menggunakan kesantunan negatif semata. Fenomena "marked" lainnya, beberapa data juga menunjukkan bahwa kedua orang tua menggunakan strategi kesantunan campuran antara kesantunan negatif dan kesantunan positif, meskipun mereka sebenarnya menempati posisi superior, pada saat bertutur kepada anak-anak mereka. 
Faktor apakah yang berkontribusi positif terhadap fenomena kesantunan yang tak lazim tersebut di atas bila ditinjau dari bingkai kerangka teori kesantunan B\&L? Menurut penulis paling tidak ada tiga variabel sosial yang berkontribusi terhadap fenomena yang marked tersebut, yakni (1) tingkat keakraban peserta tutur, (2) perbedaan usia peserta tutur, dan (3) upaya memberikan model yang baik kepada anak-anak.

Tingkat keakraban peserta tutur merujuk pada kedekatan hubungan peserta tutur. Kedekatan mereka lebih berperan dibandingkan misalnya perbedaan status sosial mereka, atau jabatan mereka, terhadap strategi kesantunan yang mereka gunakan. Pada percakapan antara bos dan bawahan di kantor (data \#27 etnik Tae Palopo), kedua peserta tutur menggunakan strategi kesantunan campuran antara kesantunan negatif dan kesantunan positif, dan bukan kesantunan positif untuk atasan sebagai superior dan kesantunan negatif untuk bawahan.

Perbedaan usia atau senioritas peserta tutur merujuk pada perbedaan baik pada tingkat usia maupun pada tingkat senioritas peserta tutur. Percakapan antara dua orang bersahabat yang berbeda usia (data \#3a-b) menunjukkan bahwa penutur yang lebih tua cenderung menggunakan strategi kesantunan positif sementara penutur yang lebih muda menggunakan strategi kesantunan negatif. Hal yang sama, percakapan antara dua orang bersaudara (data \#4) menunjukkan bahwa meskipun keduanya sangat akrab, adik secara konsisten menggunakan kesantunan negatif sementara kakak juga secara konsisten menggunakan strategi kesantunan positif. Seyogianya mereka menggunakan kesantunan positif pada saat berinteraksi karena mereka sangat akrab. Hal ini disebabkan oleh perbedaan usia kedua peserta tutur yang mengarah pada dikotomi superior-inferior. Kakak berposisi sebagai superior sedangkan adik berposisi sebagai inferior sehingga mereka menggunakan strategi kesantunan yang berbeda seperti tersebut di atas. Yang lainnya bisa dilihat pada data \#7 dan \#8 etnis Enrekang.

Faktor sosial lainnya adalah upaya orang tua memberikan model yang baik pada putraputri mereka. Pada tataran hubungan yang asimetri, secara unmarked, superior menggunakan strategi kesantunan positif bila berkomunikasi dengan inferior mereka. Sebaliknya, inferior menggunakan strategi kesantunan negatif semata. Namun, data dari seluruh etnis pada interaksi antara orang tua dengan putra-putri mereka menunjukkan bahwa orang tua umumnya menggunakan strategi kesantunan campuran antara kesantunan positif, yakni penggunaan ragam tutur yang lebih kasual, dan kesantunan negatif, yakni penggunaan ragam tutur hormat. Hal ini dimotivasi oleh upaya orang tua untuk senantiasa memberikan edukasi yang ideal tentang berperilaku sopan pada saat bertutur dengan jalan menggunakan tuturan yang sopan pada saat berkomunikasi dengan putra-putri mereka.

Berikut ini adalah fakta-fakta lain yang menunjukkan ketidakuniversalan kerangka teori kesantunan B\&L terhadap budaya bahasa-bahasa etnis Sulawesi Selatan. Kerangka teori B\&L mengklaim bahwa bentuk strategi kesantunan yang dipilih peserta tutur pada saat berinteraksi dalam konfigurasi Deference Politeness System $(-\mathrm{P},+\mathrm{D})$, misalnya, interaksi antara peserta tutur yang tidak saling mengenal adalah bentuk sapaan yang lebih hormat. Hal ini terbantahkan oleh data dialog \#(1)-(3) yang menunjukkan bahwa strategi kesantunan yang dipilih oleh peserta tutur adalah gabungan antara kesantunan positif dan kesantunan negatif sehingga pola sapaan yang dipilih oleh mereka adalah campuran antara kasual dan hormat. Dengan demikian, bentuk tuturan lebih langsung sehingga interaksi peserta tutur terasa lebih akrab.

Fenomena yang sama juga ditunjukkan oleh interaksi yang berada dalam sistem Solidarity Politeness System (-P,-D). Teori B\&L menyatakan bahwa pada sistem kesantunan solidarity, pola strategi kesantunan yang dipilih oleh peserta tutur lebih bersifat kasual sehingga 
semua atribut sosial tidak digunakan pada saat berkomunikasi. Postulat ini dibantah oleh data \#(4)-(6) di mana pola strategi kesantunan yang dipakai adalah dua ragam; kasual dan hormat, walaupun terlihat bahwa ada konsistensi yang terjadi pada data tersebut, yakni superior tetap menggunakan pola yang lebih kasual sedangkan inferior konsisten menggunakan pola yang lebih hormat.

Perbedaan hakiki yang melandasi kegagalan kerangka teori kesantunan B\&L mengelusidasi fenomena kesantunan budaya bahasa-bahasa etnis di Sulawesi Selatan dan kemungkinan juga termasuk budaya bahasa-bahasa etnis di Indonesia dan Asia. Ada aspek perbedaan latar skemata budaya yang terkandung pada konsep kesantunan yang diyakini dan diaplikasi oleh kerangka teori B\&L yang berlatar budaya Eropa-Amerika dan fenomena kesantunan budaya bahasa-bahasa warisan di Asia termasuk Indonesia. B\&L memandang kesantunan sebagai instrumen sedangkan budaya Bugis-Makassar melihat kesantunan sebagai norma yang diajarkan secara turun temurun (Yassi, 1996). Penulis berasumsi bahwa pandangan tersebut bukan hanya diaplikasi oleh budaya Bugis-Makassar, melainkan dipakai dalam masyarakat dengan budaya bahasa-bahasa di Sulawesi Selatan dan bahkan Indonesia pada umumnya.

Dengan demikian, apa pun situasi tuturnya dan siapa pun peserta tuturnya, pola strategi kesantunan yang umumnya diaplikasi oleh keempat budaya etnik Sulawesi Selatan, termasuk Indonesia pada umumnya adalah strategi kesantunan negatif, yang lebih menekankan pada aspek "hormat" (deference) dibandingkan dengan pola strategi kesantunan positif, yang lebih menekankan pada aspek "keakraban" (solidarity) yang umum dipakai dalam masyarakat dengan budaya Amerika. Hal ini sejalan dengan Lakoff (1990) yang mengatakan bahwa budaya Asia umumnya menggunakan strategi hormat. Beberapa data di atas membuktikan bahwa meskipun bentuk interaksi adalah akrab, kadang-kadang bentuk sapaan yang dipilih oleh peserta tutur adalah strategi kesantunan negatif, yakni penggunaan ragam tutur yang lebih hormat, dan bukan yang bersifat kasual, atau kesantunan positif yang menekankan keakraban.

\section{KESIMPULAN}

Terlepas dari banyaknya publikasi yang mengangkat aspek keuniversalan teori kesantunannya, khususnya yang berasal dari budaya Asia, B\&L telah meletakkan model kerangka konseptual yang kuat terhadap konsep kesantunan di dunia. Sejak diluncurkan kurang lebih empat dekade yang lalu, model teori kesantunan B\&L inilah yang paling banyak dikaji dan dikutip oleh para peneliti di dunia. Namun, sebagaimana penelitian lainnya, khususnya yang berlatar budaya Asia, penelitian ini juga telah membuktikan secara empiris aspek ketakuniversalan teori kesantunan B\&L tersebut terutama kegagalannya mempertimbangkan aspek sosial lainnya secara eksplisit yang sangat krusial terhadap pola atau sistem kesantunan suatu komunitas, yakni aspek kekerabatan dan perbedaan usia peserta tutur. Diyakini bahwa aspek kekerabatan ini sangat penting perannya dalam budaya Asia pada umumnya termasuk Indonesia. Pada aspek inilah terletak kekuatan kerangka teori kesantunan yang dibangun oleh Yassi dibandingkan kedua kerangka teori Eropa Amerika tersebut di atas. Dengan demikian, dapat disimpulkan bahwa kerangka teori kesantunan Yassi efektif untuk mengkaji fenomena kesantunan budaya bahasa-bahasa warisan bukan saja pada budaya bahasa-bahasa etnik Sulawesi Selatan melainkan juga terhadap keefektifan serta keuniversalan kerangka teori Yassi tersebut terhadap bahasa-bahasa warisan di Indonesia dan bahkan Asia pada umumnya. 
Hipotesis yang mengatakan bahwa aspek kedekatan (closeness) hubungan sosial peserta tutur berbanding lurus terhadap tingkat kasualitas tuturan yang dipilih oleh peserta tutur perlu dikaji kembali. Hipotesis ini mengatakan bahwa semakin dekat hubungan sosial peserta tutur, semakin kasual pula tuturan yang dipilih, dan semakin jauh hubungan sosial peserta tutur, semakin hormat pula tuturan yang dipilih oleh peserta tutur. Hipotesis ini tidak selamanya bekerja secara efektif. Beberapa data pada artikel ini menyajikan contoh lawan (counterexamples) terhadap hipotesis tersebut. Bahkan, berdasarkan data dari beberapa penelitian kesantunan yang dilakukan Yassi selama ini, dapat disimpulkan bahwa faktor sosial yang paling signifikan berkontribusi terhadap pola kesantunan bahasa-bahasa warisan di Indonesia adalah faktor "usia" peserta tutur. Hal ini terlihat dari data di mana atasan (superior) yang berusia lebih muda tetap memilih menggunakan kesantunan negatif (hormat) pada saat berkomunikasi dengan bawahan atau stafnya (inferior) yang berusia jauh lebih tua. Hal yang sama, interaksi antarteman tetap berpola asimetri di mana penutur yang lebih muda tetap menggunakan kesantunan negatif pada saat berkomunikasi dengan temannya yang lebih tua usianya. Oleh karena itu, apa yang dipaparkan ini terbuka untuk diverifikasi.

\section{CATATAN}

* Penulis berterima kasih kepada mitra bebestari yang telah memberikan saran-saran untuk perbaikan makalah ini. Makalah ini merupakan pengembangan dari makalah yang dibawakan pada Kongres Internasional Masyarakat Linguistik Indonesia (KIMLI 2016), di Denpasar, 24 - 27 Agustus 2016.

\section{DAFTAR PUSTAKA}

Agus, N. (2013). Bentuk kesantunan linguistik dan strategi pertuturan wanita dan pria etnis Bugis. Disertasi, tidak diterbitkan. Universitas Hasanuddin, Makassar.

Brown, R. \& Gillman, A. (1960). The pronoun of power and solidarity. Dalam P.P. Gigliogi (ed.) 1972. Language and social context. Penguin Education.

Brown, P. \& Levinson, S.C. (1978). Universals in language use: Politeness phenomena. Dalam E. Goody. (ed.), Questions and politeness: Strategies in social interaction. Cambridge: Cambridge University Press.

Brown, P. \& Levinson, S.C. (1987). Politeness: Some universals in language usage. Cambridge: Cambridge University Press

Deutchmann, M. (2003). Apologising in British English. Umea Universitet.

Gu, Y. (1990). Politeness phenomena in modern Chinese. Journal of Pragmatics, 14, 237-257.

Ide, S. (1989). Formal forms and discernment: Two neglected aspects of linguistic politeness. Multilingua, 8, 223-248.

Kitagawa, C. (1980). Saying yes in Japanese. Journal of Pragmatics, 4, 105-120.

Matsumoto, Y. (1988). Reexamination of the universality of face: Politeness phenomena in Japanese. Journal of Pragmatics, 12, 403-426

Mills, S. (2003). Gender and politeness. Cambridge: Cambridge University Press. 
Murni, M.S. (2012). Piranti bahasa dan kesantunan. Linguistik Indonesia, 30(2), 183-200.

Nadar, F.X. (2006). Penolakan dalam bahasa Inggris dan bahasa Indonesia: Kajian pragmatik tentang realisasi strategi kesopanan berbahasa. Disertasi. Yogyakarta: Universitas Gadjah Mada.

Nwoye, O.G. (1992). Linguistic politeness and socio-cultural variations on the notion of face. Journal of Pragmatics, 18, 309-328.

Reiter, R.M. (2004). Linguistic politeness in Britain and Uruguay: A contrastive study of requests and apologies. Philadelphia: John Benjamins.

Scollon, R. \& Scollon, S.B.K. (1995). Intercultural communication: A discourse approach. Oxford, Cambridge: Blackwell.

Watts, R.J. (2003). Politeness: Key topics in sociolinguistics. Cambridge: Cambridge University Press.

Yassi, A.H. (1996). Negating and affirming a proposition in Makassarese: A cross-cultural communication study. Unpublished Master's Research Paper. Department of Linguistics, The University of Sydney, NSW. Australia.

Yassi, A.H. (2011). Negating and affirming a proposition in Makassarese: Revisiting the universality of Brown and Levinson politeness theory. Dalam F. Rahman (ed.) Kebahasaan, sastra dan pendidikan. Prosiding Seminar Internasional. FIB, Universitas Hasanuddin, Makassar.

Yassi, A.H. (2012). Teori sistem kesantunan budaya bahasa Makassar. Prosiding Kongres Internasional Bahasa-Bahasa Daerah Sulawesi Selatan.

Yassi, A.H. (2016a). Model kerangka teori kesantunan yang efektif mengkaji pola kesantunan bahasa-bahasa di Indonesia: Mempertanyakan keuniversalitasan kerangka teori kesantunan Brown \& Levinson. Prosiding Seminar Antar Bangsa (ASBAM) ke-5.

Yassi, A.H. (2016b). Ancangan model kerangka teori kesantunan yang efektif mengkaji budaya bahasa-bahasa heritage di Asia: Review terhadap keuniversalitasan kerangka teori kesantunan Brown \& Levinson. Prosiding Kongres Internasional Masyarakat Linguistik Indonesia (KIMLI) 2016, Denpasar, 24-27 Agustus 2016.

Yassi, A.H. (2016c). Pemetaan pola sistem kesantunan budaya bahasa-bahasa Sulawesi Selatan dan Barat (Sulselbar): Harmonisasi kehidupan sosial bertetangga. Prosiding Seminar Nasional Bulan Bahasa Fakultas Ilmu Budaya Universitas Hasanuddin. 11-12 November 2016. Hotel Banua Makassar.

Yassi, A.H. (2016d). Pola sistem-sistem kesantunan etnik Sulselbar: Harmonisasi kehidupan sosial bertetangga. Prosiding Seminar Nasional Bulan Bahasa Fakultas Ilmu Budaya Universitas Hasanuddin. 11-12 November 2016. Hotel Banua Makassar. 